\title{
Identidades negadas, identidades construídas: processos identitários e conflitos territoriais na Amazônia
}

\author{
Edviges Marta Ioris
}

Universidade Federal de Santa Catarina, Florianópolis, Brasil

E-mail: emioris@gmail.com 


\section{Resumo}

Este texto focaliza a emergência do movimento de reelaboração das identidades indígenas que despontou no final da década de 1990 entre grupos que se encontram na área de duas reservas de proteção ambiental, na região do baixo Rio Tapajós, no estado do Pará: na Floresta Nacional do Tapajós (Flona Tapajós), criada em 1974, e na Reserva Extrativista TapajósArapiuns (Resex Tapajós-Arapiuns), criada em 1998. Reivindicando pertencimentos a etnias já consideradas extintas na região, tais como Arapium, Maytapu, Tupaiú, Tupinambá, Cara-Preta, Arara Vermelha e Mundurucu, esses grupos têm engendrado um processo de reconstrução das suas identidades indígenas e antigas tradições culturais, retomando manifestações rituais, língua, pinturas corporais, assim como construído novas formas de organização política assentadas em bases étnicas. A análise dos elementos motivadores e constitutivos desse processo demonstra que a sua dinâmica está inserida em um campo de disputas sobre os domínios identitários e territoriais que se conformou a partir de década de 1970, as quais são apreendidas em três momentos: 1) caboclo e tentativas de expulsão das terras; 2) população tradicional e reservas ambientais; e 3) indígenas e 'terra indígena'. Assim, apresenta a emergência do movimento de reafirmação étnica e cultural resultando da resistência empreendida às formas de identificação oficialmente atribuídas, e da determinação em assegurar não só a posse dos territórios, mas, principalmente, a autonomia sobre eles e seus modos de uso.

Palavras-chave: Etnogênese. Indígenas. Caboclo. Populações tradicionais. Reservas ambientais. Rio Tapajós.
Abstract

This paper focuses on the emergence of the indigenous movement of ethnic identity reconstruction, in the late 1990s, among several social groups in the area of two environmental reserves in the lower Tapajos River, Pará State: Tapajós National Forest (Flona Tapajós), created in 1974, and Tapajós-Arapiuns Extractive Reserve (Resex Tapajós-Arapiuns), created in 1998. These groups began to recognize themselves as belonging to the following ethnicities that had been considered extinct in the region: Arapium, Maytapu, Tupaiú, Tupinambá, Cara-Preta, Arara Vermelha and Mundurucu. In this process, they have made efforts to reconstruct their indigenous identities and old cultural traditions, readopting ritual manifestations, language, body painting, as well as creating new forms of political organizations founded on an ethnic basis. The analysis of the core and constitutional drives of this process shows them as embedded in a dynamic of disputes over territorial and identity domains initiated in the 1970s, which are examined in three key moments: 1) caboclo and the attempts of land displacement; 2) traditional peoples and the environmental reserves; 3) indigenous people and the Indian land. It thus underscores the emergence of the movement of ethnic and cultural reaffirmation as resistance to the types of identification that were officially attributed to those people, and in relation to the decision to ensure not only the access to their territories, but primarily the autonomous control over the land and its uses.

Keywords: Ethnogenesis. Indigenous peoples. Caboclo. Traditional people. Environmental reserves. Tapajós River. 


\section{Introdução}

— ste texto focaliza a emergência do movimento de reelaboração $\square$ das identidades indígenas que despontou no final da década de 1990 entre grupos que se encontram na área de duas reservas de proteção ambiental na região do baixo Rio Tapajós: ${ }^{1}$ na Floresta Nacional do Tapajós (Flona Tapajós), criada em 1974, à margem direita do rio; e na Reserva Extrativista Tapajós-Arapiuns (Resex TapajósArapiuns), criada em 1998, à margem esquerda. Na área da Flona Tapajós o movimento foi desencadeado pelos indígenas de Taquara, seguidos imediatamente pelos de Marituba e Bragança, os quais passaram a se reconhecer como pertencentes à etnia Mundurucu. Na área da Resex Tapajós-Arapiuns o movimento iniciou-se um ano após a criação da Reserva, quando 13 núcleos, das suas 67 comunidades, começaram a reconhecer pertencimentos a diferentes etnias já consideradas extintas, como Arapium, Maytapu, Tupaiú, Tupinambá, Cara-Preta e Arara Vermelha. Juntos, esses grupos têm engendrado um processo de reconstrução das suas identidades indígenas e antigas tradições culturais, retomando manifestações rituais, língua, pinturas corporais, assim como construído novas formas de organização política assentadas em bases étnicas.

Esse movimento de reafirmação étnica e cultural, de autorreconstrução como grupos culturalmente diferenciados, que a literatura antropológica denominaria de processos de etnogêneses (Bartolomé, 2006; Hill, 1996; Oliveira, 1999; Sider, 1976), tem significado uma alteração na composição sociocultural da região do baixo Tapajós, onde, desde finais do século XIX, apregoava-se a extinção 
dos grupos etnicamente organizados. Depois de um longo silêncio sobre os indígenas na região, esse movimento relançou a questão étnica como tema de atenção tanto acadêmica quanto político-administrativa. Em resposta às reivindicações, a Fundação Nacional do Índio (FUNAI) realizou trabalhos para identificação e delimitação de duas Terras Indígenas em 2003, e cinco em 2008, cujos resultados significarão uma alteração também no ordenamento dos espaços territoriais no baixo Tapajós.

A manifestação desse movimento, em ambas as reservas, começou quando esses grupos, aparentemente, comemoravam substantivas vitórias sobre uma sequência de disputas enfrentadas desde finais da década de 1970 para não perderem a posse de seus territórios: de um lado do rio, para evitar a expulsão das terras que sofreram sobreposição com os limites da Flona Tapajós; na outra margem, contra empresas madeireiras que insistiam em avançar sobre seus territórios. Foi precisamente quando, depois de duas décadas de luta, conseguiram afastar as ameaças de expulsão e assegurar a posse sobre suas terras que esses grupos iniciaram o movimento de reelaboração étnica e cultural e passaram a reivindicar sua regularização como 'terra indígena'.

Reescrevendo a história indígena na região, a conformação desse movimento apresenta um lócus privilegiado para se refletir sobre a dinâmica na produção das identidades sociais na Amazônia, especialmente na relação com o ordenamento dos espaços territoriais. Ao traçarmos um olhar sobre as razões que detonaram a emergência desse movimento de reafirmação étnica, encontramos uma sequência de disputas relacionadas tanto às formas de identificação social quanto à posse e ao controle de seus territórios, as quais foram se conformando sob os efeitos do projeto geopolítico para expansão das fronteiras econômicas da Amazônia, desenvolvido pelos governos militares a partir de meados da década de 1960 (Becker, 1992; Schmink e Wood, 1992). Até então, aquelas populações eram comumente 
identificadas como 'caboclas', termo que renegavam com aversão por conta dos fortes estereótipos e conotação negativa que carrega. Como vários autores já destacaram, coloquialmente 'caboclo' não é termo usado para autoidentificação, mas atribuição de outros para se referir a pessoas vistas como inferiores (Harris, 1998; Lima, 1999; Lins e Silva, 1980; Nugent, 1993; Wagley, 1976, 1985).

Além dessa forma de identificação, que já era renegada, essas populações passam a ser vítimas de novas designações em nível oficial, as quais se conformaram no contexto das disputas sobre posse e controle de suas terras, desencadeadas a partir da década de 1970, quando interesses econômicos ligados à indústria madeireira se instalam na região e avançam sobre seus territórios. Frente a todas essas formas oficiais de identificação, aqueles grupos populacionais se contrapuseram sistematicamente, configurando um forte campo de disputas identitárias (Bourdieu, 2003). Desde então, vislumbram-se três principais momentos relacionados às disputas sobre as identidades e os domínios territoriais, culminando com o movimento de reafirmação étnica e cultural. O primeiro refere-se à identificação de um 'caboclo cultural e territorialmente destituído'; o segundo, às 'populações tradicionais em áreas de reservas ambientais'; e, o terceiro, aos 'indígenas' e à reivindicação pela 'terra indígena'.

O texto aborda esses três momentos, assinalando que a emergência do movimento de reafirmação étnica e cultural decorre da resistência empreendida às formas de identificação oficialmente atribuídas que lhes tiravam os vínculos com a terra e aparavam as distinções culturais, assim como da determinação de permanecer em seus territórios, mas, principalmente, de assegurar autonomia sobre eles e seus modos de uso. Os dados apresentados resultam das investigações conduzidas sobre esse processo desde que trabalhava para a elaboração da tese de doutorado na área da Flona Tapajós, as quais foram posteriormente continuadas e ampliadas para a área Resex Tapajós-Arapiuns, através do Projeto Reafirmação Étnica e Territorial na Região do Baixo Rio Tapajós (Projeto RETER). ${ }^{2}$ 


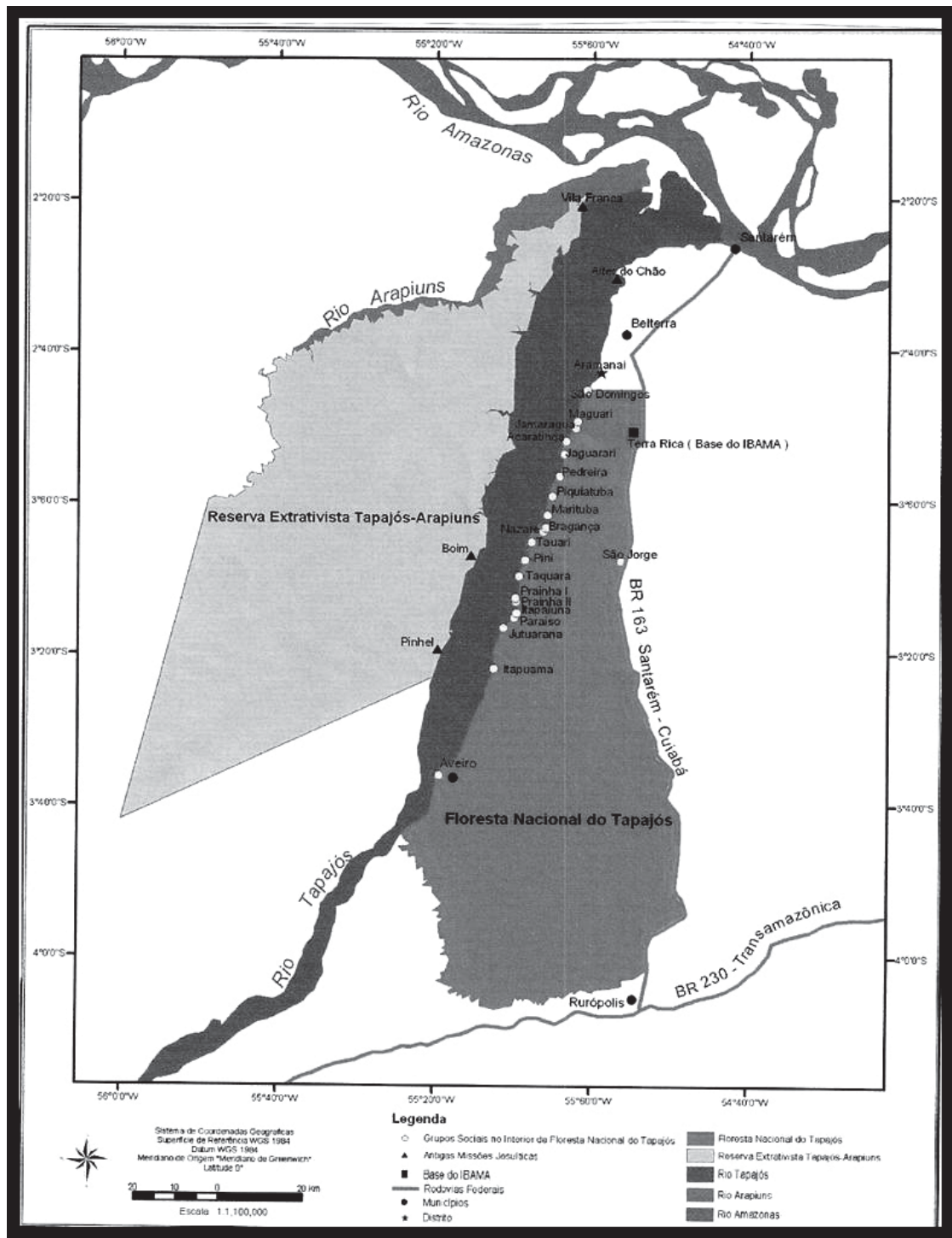

Figura 1: Reserva Extrativista Tapajós-Arapiuns e Floresta Nacional do Tapajós, na região do baixo Rio Tapajós

\section{História, identidades e territórios no baixo Tapajós}

Não obstante as diferentes referências étnicas reivindicadas pelos vários grupos indígenas na área daquelas duas reservas florestais, eles compartilham o mesmo padrão de organização sociocultural e 
de ocupação da terra, o qual é resultante de um longo e impactante processo de contato, iniciado quando a colonização adentrou a foz do Rio Tapajós, no século XVII, e se estendeu sobre seus territórios. Esse processo causou transformações tão profundas nas instituições e modos de vida dos grupos nativos da então populosa e etnicamente diversificada região do baixo Tapajós, que eles chegaram a ser considerados extintos pouco mais de dois séculos depois (Bates, 1979; Meggers, 1977; Menéndez, 1981, 1992; Nimuendaju, 1949; Parker, 1985; Ribeiro, 1979; Santos, 1999). A sua compreensão depende, portanto, de uma perspectiva histórica que situe esses grupos em um mesmo contexto sociopolítico e cultural, moldado no decurso da ocupação colonial - de uma "situação histórica" nos termos de Oliveira (1988) - cujo intento visava deslocar as populações indígenas de seus domínios culturais e territoriais, e reacomodá-las de modo a atender aos interesses que se instalavam na região e necessitavam de sua mão de obra.

O primeiro movimento nesse sentido foi promovido pelas Missões Jesuíticas, as quais foram estabelecidas em cinco locais diferentes na região do baixo Tapajós. ${ }^{3}$ Dessa forma, reunindo etnias diversas sob um mesmo regime linguístico, de organização religiosa e de trabalho, transformaram um contexto multiétnico e multilinguístico em um ordenamento socioespacial que aparava as diferenças culturais e estabelecia uma unidade linguística assentada na Língua Geral Amazônica (LGA), que veio a ser conhecida como Nheengatu (Bessa Freire, 2003). Ao longo de quase um século, até serem expulsas em 1750, essas missões cumpriram duplo papel, o de assegurar o alargamento das fronteiras coloniais lusitanas e o de promover um movimento para homogeneizar cultural e linguisticamente uma mão de obra indígena oriunda de diversos e distintos grupos étnicos. Esse movimento iniciado pelas missões religiosas foi intensificado, logo a seguir, com o projeto pombalino do Diretório dos Índios, cujas políticas assimilacionistas visavam, igualmente, forçar novos acomodamentos nas formas de organização socioculturais existentes para disponibilizá-la ainda mais largamente como mão de obra, atendendo aos interesses do projeto agrícola que se intentava para a 
Amazônia (Almeida, 1997; Menéndez, 1981, 1992; Moreira Neto, 1971; Parker, 1985).

O curso das mudanças produzidas pelas políticas do projeto colonial foi dramaticamente alterado no momento seguinte, na transição para o recém-criado Estado brasileiro, com o levante da Cabanagem, que ocorreu entre as décadas de 1830-40, reconhecido como o mais popular entre os movimentos que se rebelaram contra as forças imperiais por ter sido conduzido, em sua grande expressão, pelas populações indígena, negra e mestiça (Di Paolo, 1990). A revolta da Cabanagem teve fortes implicações para os grupos nativos do baixo Tapajós, onde se conformou um dos principais focos de resistência e, por um breve período, chegou a fazer de Santarém um centro político autônomo (Di Paolo, 1990; Reis, 1979; Santos, 1999). A massiva participação daquela população indígena recém-saída das políticas coloniais tornou-a alvo central das forças de combate e da repressão que se seguiu, cujas ações fizeram perecer larga parcela desses indígenas e causaram intensos movimentos de fugas, que deixaram esvaziadas as terras ao longo das margens do Tapajós.

Tais efeitos foram observados pelo naturalista inglês $\mathrm{H}$. Bates (1979) ainda na década de 1850, quando visitou Santarém e registrou que a Cabanagem teria causado uma diminuição de $30 \%$ da sua população, assim como em Alter do Chão, aldeia dos índios Borary, notou que "poucos deles escaparam ao massacre subseqüente, e por esta razão quase não se vêem homens velhos e de meia-idade no vilarejo" (p. 161). O terror aos confrontos e à repressão que se seguiu ao levante da Cabanagem ainda ressoa de forma intensa nos atuais relatos dos indígenas, que recorrentemente enfatizam os movimentos de fugas vivenciados por seus antepassados para escapar da "guerra", ${ }^{4}$ como eles costumam se referir ao levante:

O que minha avó e minha bisavó falavam eram que os avôs delas, que eram o José e Joana Tupaiú, foram morar lá dentro da mata fugindo daqui porque existia uma guerra. Tinha esta guerra e eles tiveram que fugir, correr para dentro da mata, onde não podiam fazer fogo à noite, nem de dia, porque eles podiam ser achados. Eles moravam em buracos, nestes buracos que dá no chão quando a árvore tomba. Ali naquele buraco no 
chão, feito da raiz grande, eles ficavam morando, ficavam escondidos, sem poder fazer casa. Eles moravam em buracos porque eles tinham medo que as pessoas vinham buscar eles pra ser escravo. Eles moravam no buraco do pau, eles moravam no buraco da terra. Eles faziam buraco na terra pra viver. Muitos parentes também viviam lá... Naquela época eles tinham medo, muito medo que o exército viesse buscar eles pra levar pra guerra.

As fugas para as áreas mais centrais decorrentes dos confrontos da Cabanagem promoveram o que se pode chamar de uma 'reinteriorização' das populações indígenas, depois de dois séculos em que grande parte havia sido 'descida' para residir nas Missões dos Jesuítas. Talvez isso explique por que os naturalistas, viajando pelo baixo Tapajós no século XIX, não registraram ter encontrado grupos indígenas ao longo de suas margens, mas apenas "vestígios das antigas aldeias" (Coudreau, 1977, p. 17). Esse movimento de retorno ao centro das matas só foi alterado com o desenvolvimento da economia da borracha, no final do século XIX, quando começaram a restabelecer uma relação com as áreas da beira do Tapajós. Até então, reconstruindo-se sob os estilhaços da Cabanagem, esses grupos interiorizados foram estabelecendo e consolidando um padrão de organização sociocultural e de ocupação da terra que se reproduz, apesar de variações, até os dias atuais. ${ }^{5}$ A conformação social desses grupos tendeu a ser largamente identificada como 'cabocla', e seu padrão de organização sociocultural e de ocupação da terra tem sido comumente associado à formação de um campesinato tipicamente amazônico (Galvão, 1955; Harris, 1998; Lima, 1999; Lins e Silva, 1980; Nugent, 1993; Parker, 1985; Wagley, 1976, 1985).

Identidades negadas: não obstante a identificação como 'caboclo', esses grupos, como indicado, tendem a renegar essa controversa e multifacetada categoria que, de forma geral, é atribuída às populações amazônicas fortemente marcadas em suas trajetórias históricas pelos efeitos das políticas coloniais. Renegam, certamente, por saberem que, como tal, tanto coloquial quanto academicamente, elas têm sido repetidamente retratadas em termos de ausências culturais, pelo que perderam, pelo que deixaram de ser, como resquícios de sociedades que sucumbiram. O texto de Parker (1985) 
sobre a emergência histórica do 'caboclo' como categoria social na Amazônia é ilustrativo dessa perspectiva, definindo a sua conformação como resultado de "Ameríndios destituídos e privados culturalmente e descendentes mestiços engajados em inconstantes atividades de subsistência e coleta de produtos florestais (p. 35)". Opondose a essa visão, Nugent (1993, p. 21) observa que, em decorrência de essas sociedades "camponesas caboclas" terem surgido "entre os interstícios do aparato colonial, nunca lhes foi outorgado status de formas sociais integrais".

Preocupado em desvendar as razões históricas que têm obscurecido a apreensão dessas sociedades em seu pleno direito, Nugent (1993) examinou as várias representações atribuídas ao 'caboclo', tanto na esfera política quanto acadêmica, através das quais identificou a produção de uma invisibilidade que se lançou sobre elas, a qual se refletiria na sua ausência tanto entre as políticas públicas (sejam elas estabelecidas por agências governamentais ou multilaterais) quanto nos estudos acadêmicos. Para o autor, as raízes dessa invisibilidade estariam localizadas na projeção da Amazônia como "um domínio natural no qual o social é intrusivo" (p. 20) e em certa patologia atribuída ao 'caboclo', visto como se fosse um "elo perdido" entre civilização e natureza, que se encontra sem laços que o conecte com as sociedades pré-coloniais e, ao mesmo tempo, incapaz de reconstruir uma nova sociedade. Assim, não consideradas como sistemas sociais integrais, as sociedades caboclas teriam sido negligenciadas nos programas governamentais e despertado pouco interesse nos meios acadêmicos.

A análise traçada por Nugent representa uma abordagem inovadora sobre a construção da categoria de 'caboclo', na qual destaca os mecanismos de poder que alimentam e sustentam as sucessivas distorções e estereótipos nas representações sobre suas organizações sociais, e as implicações políticas e econômicas que se refletem nos gabinetes oficiais, desqualificando-os como beneficiários de seus programas. Tem o mérito, ainda, de atualizar, entre as mais recentes perspectivas teóricas do debate antropológico, um objeto de estudo que já se encontrava bastante esquecido; e, principalmente, de cha- 
mar atenção para a necessidade de se repensarem as dinâmicas na reconfiguração populacional pós-colonial na Amazônia, assim como as formas como esses grupos sociais fortemente impactados pelas políticas coloniais têm sido representados tanto na academia quanto nos programas das políticas públicas.

Contudo, para o nosso caso, a perspectiva da invisibilidade apresenta limitações para apreender as disputas em torno das identidades sociais dos grupos que se encontram nas áreas das duas reservas ambientais, aos quais também foi imputada a categoria de 'caboclo'. A ênfase em desvelar os sustentáculos da produção e manutenção de invisibilidades virtuais, que teriam mantido as chamadas populações 'caboclas' fora das agendas políticas ou acadêmicas, acaba por projetálas como vítimas de desconsideração, de esquecimento, como sendo de pouca importância para os objetivos e design dos seus programas ${ }^{6}$. A noção de invisibilidade, nesse sentido, tende a tirar de foco dois aspectos fundamentais para a compreensão das disputas relacionadas às diferentes formas de identificação e representação que se observam entre os grupos na área daquelas duas reservas ambientais.

Em primeiro lugar, se invisíveis aos olhos do Estado, essa perspectiva ofusca a projeção desses grupos como objeto de atenção das suas políticas, limitando, por exemplo, apreender a importância da produção estatal no jogo de categorizações que se conformou, assim como do programa de criação das reservas ambientais. Em segundo lugar, tende a ofuscar as estratégias e as formas de reação e resistência impetradas pelos grupos locais às diferentes formas de atribuição que lhes foram impostas. Entretanto, como sugere uma leitura de Foucault (1984), se quisermos compreender os efeitos de poder, temos que parar de descrevê-los sempre em termos negativos, de que 'exclui', 'reprime', 'abstrai', 'esconde', e entender que o "poder produz; ele produz realidade; produz campos de objeto e rituais da verdade" (p. 172). Nessa perspectiva, um olhar atento sobre as diversas formas de identificação oficialmente atribuídas àqueles grupos sociais no baixo Tapajós, nas últimas quatro décadas, pode observar que eles não padeceram de esquecimento ou negligência nos programas governamentais. Ao contrário, estavam bastante visíveis e foram sis- 
tematicamente objeto de significativa atenção nas políticas de Estado, especialmente no projeto de ordenamento espacial. E foi na reação desses grupos às sucessivas formas de atribuição que se conformaram as disputas sobre as suas identidades, as quais culminaram com o movimento de reelaboração das identidades indígenas entre grupos de ambas as reservas ambientais, no final da década de 1990.

Assim, para compreender esse processo, não se pode abordá-lo como produto de negligências, de invisibilidades. É preciso, ao contrário, buscar precisamente as suas visibilidades (Haraway, 1991), de como esses grupos foram pensados, construídos, representados nos programas oficiais desde a implantação do projeto geopolítico dos militares na década de 1960. Os processos identitários, assinala Oliveira (1999, p. 20), "devem ser estudados em contextos precisos e percebidos também como atos políticos". Nesse sentido é preciso buscar entender também como atos políticos as reações de resistência desses grupos às sucessivas denominações que lhes foram atribuídas. Através dessas reações eles demonstram saber, assim como Bourdieu (2003) observa, que tais categorizações não são destituídas de significados, e que o seu acomodamento em uma ou outra forma de identificação tem implicações diretas sobre seus direitos territoriais.

Resistiam, portanto, não para sair da invisibilidade, mas para traçar uma visibilidade diferente daquelas oficialmente projetadas sobre eles e que lhes abstraía direitos territoriais. Desse modo, as disputas identitárias, como se verá a seguir, estavam diretamente relacionadas às disputas sobre o acesso e, o controle dos territórios, as quais podem ser acompanhadas em três momentos: 1) de um caboclo cultural e territorialmente destituído que quase foi expulso das terras que ocupava; 2) de uma população tradicional concebida junto às reservas ambientais; e 3) dos indígenas que se mobilizam pelo reconhecimento de seus territórios como 'terra indígena'. 


\section{Expansão das fronteiras madeireiras e identidades sociais}

A partir da década de 1970 o baixo Tapajós começou a enfrentar significativas mudanças. Elas foram promovidas pelas políticas de incentivos ao desenvolvimento de uma indústria madeireira regional, criadas pelos governos militares no âmbito do projeto geopolítico para expansão das fronteiras econômicas na Amazônia, que visava ampliar a ocupação e acelerar o desenvolvimento econômico. Nesse sentido, com o objetivo de alavancar a modernização da indústria regional e assegurar mercado exportador para a produção, o governo disponibilizou grandes investimentos para a construção de uma extensa rede viária e portuária, para a elaboração de programas de incentivos fiscais e para a produção de conhecimento técnico e científico (Barretto, 2001a, 2001b; Becker, 1992; Guimarães, 1991; Schmink e Wood, 1992).

Em termos desse conhecimento, o governo federal promoveu um vasto inventário dos recursos florestais na Amazônia, através do Projeto de Desenvolvimento e Pesquisa Florestal (PRODEPEF), coordenado pelo extinto Instituto Brasileiro de Desenvolvimento Florestal (IBDF). Os principais objetivos do PRODEPEF eram fortalecer técnica e institucionalmente o IBDF, estabelecer uma base de dados sobre os recursos florestais para dar suporte ao projeto de modernização da indústria florestal, especialmente a produção madeireira, e definir áreas para reservas florestais (FAO/IBDF, 1978). Esses levantamentos foram ampliados e intensificados no II Plano de Desenvolvimento da Amazônia (PDAM II), lançado 1974, para promover polos de desenvolvimento econômico na Amazônia (PoloAmazônia).

Nessa concepção, o PDAM II destinou o vale do Rio Tapajós para o desenvolvimento de um 'polo industrial madeireiro', cuja designação seguia a trilha aberta pela missão da Organização das Nações Unidas para Alimentação e Agricultura (FAO $)^{7}$ no início da década de 1950, quando conduziu os primeiros inventários florestais na Amazônia, já então visando à modernização da indústria madeireira (Ioris, 2008). A continuidade desses esforços deveria transformar a exploração madeireira na região numa atividade planejada, institucionalizada e permanente. A ênfase deveria ser deslocada para 
a exploração da floresta em 'terra firme', substituindo a exploração que ocorria em áreas de várzea com as chamadas madeiras leves pela exploração das chamadas madeiras pesadas, visando à exportação. Com essas metas, a partir de 1980 o governo federal disponibilizou massivos subsídios fiscais para estimular a introdução das espécies de madeira pesada da Amazônia no mercado internacional (Browder, 1987).

A designação do vale do Tapajós para desenvolvimento e modernização de um polo industrial madeireiro promoveu dois eventos que ameaçaram seriamente a posse e o padrão de ocupação da terra das populações nativas de ambas as margens do rio: 1) a criação da Floresta Nacional do Tapajós, em 1974, na margem direita; 2) e a entrada de empresas madeireiras, na margem esquerda. Em ambas as situações ocorreram fortes enfrentamentos na luta pela defesa da terra por parte dessas populações, que eram, de modo geral, identificadas como 'caboclos'. Elas, por sua vez, como assinalado, renegavam essa categorização e tendiam a se autoidentificar como pertencentes às suas respectivas 'comunidades': "pertenço à comunidade de Taquara, à comunidade de Pinhél, à comunidade de Muratuba...".

Composta de núcleos familiares extensos, a 'comunidade' configura uma unidade político-espacial. Ela denota um conjunto de direitos comuns de residência e usos comunais dos recursos sobre determinada extensão de terra, assim como das formas associativas e representativas, conferindo aos seus membros autonomia sobre as decisões internas e sobre um espaço territorial. A introdução do termo é atribuída aos trabalhos de organização popular das Comunidades Eclesiais de Base (CEBs), da Igreja Católica, desenvolvidos a partir da década de 1960, quando, segundo seus relatos, começaram a deslocar suas moradias dos centros das matas para fixá-las nas áreas da beira do rio. A efetivação dos trabalhos das CEBs, a princípio de caráter essencialmente religioso, levou esses núcleos domésticos a incorporarem um ideal de 'comunidade' enquanto grupos socialmente articulados, o qual foi gradualmente absorvendo as instâncias político-administrativas e territoriais. ${ }^{8}$ Em poucas palavras, a 'comunidade' transformou-se na principal forma de representação e organização sociopolítica e espacial entre as po- 
pulações nativas na região do baixo Tapajós até a década de 1970, quando interesses vinculados à exploração madeireira começaram a se instalar na região.

\section{Floresta Nacional do Tapajós e as tentativas de expulsão} da terra: a Flona Tapajós foi criada no município de Santarém, ${ }^{9}$ com uma área aproximada de 600 mil hectares, tendo o Rio Tapajós como limite oeste, a rodovia Santarém-Cuiabá ao leste e o Rio Cupari ao sul. Ela foi a primeira reserva florestal efetivamente implementada na Amazônia, conduzida pelo extinto IBDF. Tendo por objetivo a exploração sustentada de madeira, as Florestas Nacionais integram o conjunto de reservas denominadas 'unidades de conservação'. Estas unidades de conservação fazem parte do Sistema Nacional de Unidades de Conservação da Natureza (SNUC), que define e regulamenta as reservas ambientais no país, as quais estão atualmente sob responsabilidade do Instituto Brasileiro do Meio Ambiente e dos Recursos Naturais Renováveis (IBAMA) e do Instituto Chico Mendes, órgãos do Ministério do Meio Ambiente.

Inaugurando a implantação de um sistema de reservas ambientais na Amazônia, a Flona Tapajós, no entanto, teve seus limites sobrepostos aos territórios de vários grupos sociais, não só dos indígenas de Taquara, Marituba e Bragança, como também de outras 16 comunidades ${ }^{10}$ igualmente localizadas na margem direita do Tapajós. Como naquele momento a legislação das Florestas Nacionais não permitia a permanência de nenhum residente no interior das reservas, a administração da Flona Tapajós iniciou um processo de desapropriação das terras das populações que lá se encontravam, o que acabou gerando intensos conflitos (IMAFLORA/IBAMA, 1996).

Essas populações não aceitaram as medidas para desapropriação e, organizadas em 18 comunidades, impetraram forte resistência para permanecer em suas terras e assegurar o acesso aos recursos florestais. O movimento de resistência foi marcado por sucessivos embates com o órgão ambientalista governamental, levando-as a se engajarem em formas mais amplas de articulação política, cujo principal instrumento foi o Sindicato dos Trabalhadores Rurais de Santarém. Dessa forma, empreenderam diversas estratégias de lutas, 
incluindo a autodemarcação de uma área para que fosse excluída dos limites da Flona Tapajós. Até então, a maioria dessas pessoas não participava de qualquer forma de organização política que representasse seus interesses fora das suas comunidades. Como informavam: "foi através das delegacias sindicais que nós começamos a buscar a maneira de questionar e resolver o problema da terra". Naquele momento em nenhuma dessas comunidades havia reivindicações por uma identidade étnica diferenciada.

Em reposta ao movimento de resistência, o IBDF decidiu, então, excluir uma área da Flona Tapajós para as comunidades, cujo tamanho tornou-se objeto de disputa de difícil resolução. Sem estabelecer uma negociação com representantes das comunidades, o IBDF contratou em 1983 os serviços topográficos do $8^{\circ}$ Batalhão de Engenharia e Construção do Comando Militar da Amazônia ( $8^{\circ} \mathrm{BEC}$ ) para demarcar uma área de 27.600 hectares que seria excluída dos limites da Flona. Em setembro, quando estava realizando a demarcação da área, funcionários do $8^{\circ}$ BEC foram surpreendidos pelos comunitários, que exigiram a paralisação dos trabalhos.

Por seu lado, as comunidades resolveram fazer a própria demarcação como forma de garantir a área que desejavam. Assim, em maio de 1984 elas se juntaram para realizar a demarcação, distante aproximadamente dez quilômetros da margem do rio até o centro de floresta. Essa linha demarcatória foi denominada "Pico das Comunidades", em oposição ao "Pico do IBDF". Apesar de essa linha demarcatória ter sido materializada, a administração da Flona Tapajós não reconheceu tais limites. Através de sucessivos embates as comunidades foram garantindo extraoficialmente o domínio da área até finais da década de 1990, quando houve mudança na legislação das Florestas Nacionais, permitindo a partir de então a permanência das populações na área daquela reserva.

Madeireiras: invasão e redução territorial: enquanto as populações nativas lutavam na margem direita do Tapajós para não serem expulsas de suas terras, em decorrência da criação da Flona Tapajós, as que se encontravam na outra margem empreendiam luta semelhante, porém contra empresas madeireiras. Aproveitando os 
incentivos governamentais para exploração e produção madeireira, duas empresas sediadas em Belém, estado do Pará, começaram a se instalar na região do baixo Tapajós, precisamente na área da atual Reserva Extrativista Tapajós-Arapiuns: a Amazonex Exportadora Ltda. e a Santa Isabel Agroflorestal Ltda. Essas duas empresas

[...] tinham a pretensão de ocupar a margem esquerda do Tapajós numa extensão de cerca de $60 \mathrm{~km}$ de frente, de Cametá, no município de Aveiro, até o rio Arapiuns, por $100 \mathrm{~km}$ de fundo... As empresas não usavam de violência aberta, mas da desinformação, da ocupação silenciosa e insidiosa, das promessas de progresso e empregos, e da autoridade do INCRA ${ }^{11}$ (Leroy, 1991, p. 116).

Segundo Leroy (1991), que naquele momento trabalhava na Federação de Órgãos para Assistência Social e Educacional (FASE) ${ }^{12}$ assessorando o movimento sindical em Santarém, a entrada das madeireiras era facilitada pelo Instituto Nacional de Colonização e Reforma Agrária (INCRA), através do programa de regularização fundiária, que conduzia levantamentos de ocupação em que

[...] os seus funcionários só levavam em conta os terrenos da beira do rio, arenosos, cansados e infestados de saúva. Acontece que os lavradores moravam lá em função da água, dos peixes e do transporte, mas boa parte da sua atividade econômica era voltada para o centro, a mata, onde plantavam o roçado de mandioca, exploravam a seringueira e apanhavam a castanha. As famílias de lavradores, nesta operação a serviço dos madeireiros, viam reduzido seu espaço de sobrevivência à casa, ao quintal e um ou dois hectares de terra imprestável. Sua luta, portanto, ao exigir a garantia do espaço da sua reprodução, voltava-se tanto contra o INCRA, quanto contra as empresas (p. 116).

Dessa forma, mobilizando-se também através do Sindicato dos Trabalhadores Rurais de Santarém, esses grupos de comunidades se impuseram a essas empresas e conseguiram estabelecer limites a partir de onde elas poderiam adentrar as áreas de mata. Os limites acordados com as empresas compreendiam uma área que se estendia até 13,4 quilômetros da beira do rio até o centro da mata. As empresas madeireiras somente poderiam explorar os recursos flo- 
restais que se encontravam além desses limites. Assim, para assegurar a posse e o controle sobre essa extensão de terras, as comunidades também se uniram para realizar os trabalhos demarcatórios e mantiveram constante vigilância sobre a área. Tal situação perdurou até meados da década de 1990, quando elas começaram a se articular para a criação da Reserva Extrativista Tapajós-Arapiuns.

Identidade sindical e garantia de posse da terra: em ambas as situações, tanto nas terras na margem esquerda quanto nas terras na margem direita do Rio Tapajós, os núcleos populacionais enfrentaram sérias ameaças à posse e à manutenção do padrão de ocupação da terra que reproduziam desde os tempos da revolta da Cabanagem. Até o advento daqueles empreendimentos, os grupos nativos organizados em torno de suas comunidades mantinham poucos e diferenciados vínculos entre eles, os quais resultavam basicamente de alguns laços de parentesco, participação nos trabalhos coletivos de roçados ou festas religiosas. Foram as ameaças aos seus territórios e o movimento de resistência impetrado que estreitaram as relações entre eles, gerando uma nova unidade sociopolítica. No caso da Flona Tapajós, diante das tentativas governamentais de desapropriação; no caso das empresas madeireiras, frente às tentativas de reduzir e comprometer seu modo de ocupação da terra.

O envolvimento no movimento de defesa dos territórios levou à conformação de uma unidade de coesão entre as várias comunidades afetadas, dinamizada através do Sindicato dos Trabalhadores Rurais de Santarém, que configurou a primeira forma de organização política supracomunitária entre elas. Sobre aqueles frouxos laços que se estabeleciam entre as comunidades em ambas as margens do Tapajós, a luta pela terra trouxe uma nova forma de articulação política, e essa associação ao Sindicato adicionou novas formas de pertencimentos e identificação, quando passam a fazer 'parte do sindicato' e se reconhecer como 'sindicalizados/as'. Foi como 'sindicalizadas' que essas populações conseguiram evitar as desapropriações que estavam em curso e assegurar a posse e a manutenção de seu padrão de ocupação da terra. Em 1996, durante minha primeira visita às comunidades na área da Flona Tapajós, era comum as pessoas se apresentarem como 'sindicalizadas'. 
Se a mobilização em defesa da terra através do Sindicato dos Trabalhadores Rurais adicionava uma nova forma de identificação a essas populações, na esfera governamental elas também se tornavam objeto de identificações diversas. Especialmente em relação à Flona Tapajós, da qual se pode dispor de documentos oficiais, observa-se uma variedade de termos aplicados para identificar as populações residentes, os quais foram variando ao longo de sua implantação. Inicialmente, logo que a Flona Tapajós foi criada, quando a sua administração empreendia esforços para desapropriar as suas terras, essas populações eram descritas, além do termo 'caboclo', como 'posseiras', 'ocupantes ocasionais' e, em alguns casos, até como 'invasoras'. Frente ao movimento de resistência, as 18 comunidades localizadas na margem direita do Rio Tapajós passaram a ser identificadas indistintamente como "comunidades ribeirinhas da Flona Tapajós" (Ioris, 2005). Em finais da década de 1990, novamente ocorreram mudanças nas formas de identificação dessas populações.

\section{Populações tradicionais em áreas de reservas ambientais}

Enquanto na década de 1980 as populações nativas do baixo Tapajós enfrentaram ameaças diretas à manutenção dos territórios, causadas pelo avanço da economia madeireira, em meados da década seguinte elas começam a vislumbrar direitos territoriais serem reconhecidos oficialmente. Esse fato ocorreu no contexto das intensas e amplas mobilizações que se configuraram na Amazônia entre grupos ambientalistas e segmentos das suas populações rurais, especialmente aquelas cujos modos de vida dependiam da manutenção da floresta, em reação aos alarmantes níveis de degradação ambiental e ameaças à integridade dos territórios dessas populações que se evidenciavam por toda a região. Essa mobilização contava com apoio de organismos internacionais, que orquestraram intensa campanha contra o acelerado ritmo de desmatamento da Floresta Amazônica, tornando-a centro das preocupações ambientalistas internacionais e exercendo forte pressão sobre o governo brasileiro para adoção de medidas de proteção ambiental e dos direitos territoriais das popula- 
ções que a habitam (Allegretti, 2002; Almeida, 2004; Barretto, 2001; Cunha e Almeida, 2001; Esterci, 2002; Hurrel, 1992).

A associação entre as agendas de defesa ambiental e dos direitos territoriais dos povos amazônicos ganhou força com a mobilização para a criação de Reservas Extrativistas, desencadeada pelo movimento dos seringueiros no estado do Acre, visando assegurar a posse das terras e a manutenção das áreas de floresta. Como destacou Barretto (2001, p. 22), foi também nesse movimentado período que começou o reconhecimento pelo poder público dos grupos sociais, que passaram a ser chamados de 'populações tradicionais'. Esse reconhecimento se expressava de diversas formas, tanto em dispositivos legais quanto na criação de organismos governamentais para lidar com elas, como foi o Centro Nacional de Desenvolvimento Sustentado das Populações Tradicionais (CNPT), criado pelo IBAMA, em fevereiro de 1992 (Portaria $\mathrm{n}^{\circ}$ 22, de 10 de fevereiro de 1992), tendo por responsabilidade a criação e a implementação das Reservas Extrativistas. A criação daquele Centro integrava-se ainda aos preparativos para a Conferência das Nações Unidas sobre Meio Ambiente e Desenvolvimento, a ECO-92, realizada em 1992, no Rio de Janeiro.

Os efeitos mais amplos do movimento de reconhecimento dos direitos territoriais das 'populações tradicionais' se estenderam também sobre os grupos sociais na região do baixo Tapajós, em ambas as margens do rio. Entre eles registraram-se dois movimentos que significaram mudanças substanciais na condução da luta pela terra: de um lado, na margem direita do rio, na área da Flona, com a mudança na legislação das Florestas Nacionais, que passou a admitir a permanência dessas populações na reserva; e, de outro lado, na margem esquerda, com a criação da Reserva Extrativista Tapajós-Arapiuns e a consequente retirada das madeireiras.

Mudanças na legislação das Florestas Nacionais e na identificação dos grupos sociais: conforme enfatizado, as comunidades na área da Flona Tapajós, organizadas através do Sindicato dos Trabalhadores Rurais, conseguiram evitar as desapropriações que estavam em curso e garantiram extraoficialmente o domínio da área que reivindicavam, a qual compreendia os dez quilômetros da mar- 
gem do rio até o centro da mata. Durante esse processo, a relação entre as comunidades e as agências governamentais responsáveis pela administração da Flona era extremamente conflituosa e marcada por desconfianças e hostilidades (Fatheuer, 1998). A partir de meados da década de 1990 essa relação começou a ser revista pelas agências governamentais responsáveis pela administração da reserva.

Além daquele contexto de discussão mais amplo sobre direitos territoriais das 'populações tradicionais', vários fatores tiveram influência direta para essa mudança de postura. Entre eles destaca-se o Programa Piloto para a Proteção das Florestas Tropicais do Brasil (PROMANEJO/PPG-7), lançado durante a ECO-92 e desenvolvido na Flona Tapajós através do Componente IV do Programa. Depois de vários ajustes técnicos e institucionais, o PROMANEJO começou a ser implementado na Flona em 1995, com o objetivo geral de desenvolver e testar modelos de conservação e usos sustentáveis dos recursos naturais em reservas florestais na Amazônia, tendo como ênfase a participação da sociedade civil. De forma mais específica, buscava-se desenvolver um modelo de exploração florestal a ser reproduzido nas demais florestas nacionais na Amazônia (Fatheuer, 1998; IMAFLORA/IBAMA, 1996).

De início, entre os anos de 1995 e 1996, foram realizadas as atividades de pré-investimento, orientadas para a elaboração de um Plano Diretor participativo da Flona Tapajós e para ajudar técnica e institucionalmente a administração da reserva a superar os entraves que persistiam, como era o caso da regularização fundiária. Logo se evidenciaram os conflitos decorrentes da permanência das 18 comunidades localizadas na margem direita do Rio Tapajós, os quais foram percebidos como principal obstáculo à implantação do PROMANEJO na área da Flona Tapajós. Dessa forma, identificou-se que a resolução dos conflitos e a definição de uma área para aquelas comunidades eram condições para a elaboração de um Plano Diretor da Flona Tapajós, e que as atividades de pré-investimento deveriam atender a essas metas.

Assim, conduzidos pelo Instituto de Manejo e Certificação Florestal e Agrícola (IMAFLORA) ${ }^{13}$, os trabalhos junto às comunidades 
foram desenvolvidos numa sequência de atividades, envolvendo oficinas de discussão, estudos e levantamentos socioculturais e ambientais, os quais subsidiaram a elaboração de uma proposta de área que seria designada para as comunidades. Elas reivindicavam que essa área proposta fosse excluída dos limites da Flona Tapajós, pois não mais queriam a interferência do IBAMA sobre seus territórios. Em 1996, também tramitava no Congresso Nacional um Projeto de Lei para exclusão das áreas onde se encontravam as populações na Flona Tapajós, inclusive as 18 comunidades, para as quais se aguardava a proposta dos limites que seriam estabelecidos (IMAFLORA/ IBAMA, 1996). Neste mesmo ano, durante os trabalhos de pré-investimento do PROMANEJO, havia sido promovida uma consulta junto às comunidades sobre o destino que pretendiam para a área que lhes seria designada. O resultado indicou que $62 \%$ das pessoas queriam que as suas terras fossem excluídas dos limites da Flona Tapajós.

Os representantes do IBAMA, por sua vez, discordavam da proposta de redução dos limites da Flona Tapajós e passaram a defender a permanência das comunidades na área da reserva, onde teriam uma área de uso cuja extensão seria designada através da elaboração do plano de manejo. Essa posição tomada pelo IBAMA refletia as mudanças que estavam em curso na legislação das Florestas Nacionais através da nova versão do SNUC, que foi aprovada e sancionada em 2000 (SNUC, 2000, Lei Federal no 9.985, de 18 de julho de 2000). Nessa versão do SNUC, no artigo 17, referente às Florestas Nacionais, o texto amplia o conceito dessa categoria de reserva, designando-a para um "uso múltiplo sustentável dos recursos naturais" e não apenas para a exploração madeireira, como era anteriormente. Também estabelece que nelas "é admitida a permanência de populações tracionais que a habitam quando de sua criação, em conformidade com o disposto em regulamento e no Plano de Manejo da unidade". Como veremos adiante, além das Florestas Nacionais, o SNUC também contempla 'populações tradicionais' em outras duas categorias: nas Reservas de Desenvolvimento Sustentável (RDS) e nas Reservas Extrativistas (RESEX). O artigo 18, referente às Reservas Extrativistas, menciona "populações extrativistas tradicionais". 
Dessa forma, passando a ser identificadas como 'populações tradicionais' (e não apenas como 'caboclos', 'posseiros', 'ocupantes ocasionais' ou 'comunidades ribeirinhas'), as comunidades na Flona Tapajós tiveram sua permanência 'admitida' no interior da reserva, assegurando o direito de permanecer em suas terras. Nessa nova conformação o IBAMA empreendeu esforços para que as áreas de uso fossem incorporadas no plano de manejo da reserva e conseguiu retirar a exclusão da área dessas comunidades do Projeto de Lei que estava em discussão no Congresso. Essa mudança na legislação da reserva afastou as ameaças de desapropriação, porém, por outro lado, frustrou as expectativas das pessoas que pretendiam o fim da interferência do IBAMA sobre suas terras.

A criação da Resex Tapajós-Arapiuns: enquanto as comunidades da Flona Tapajós passavam pelo processo de serem consideradas como 'população tradicional' e viam admitida a sua permanência na área da reserva, as comunidades na outra margem do Rio Tapajós, assim como na margem direita do Rio Arapiuns (afluente do Tapajós), viviam processo semelhante. Também passaram a ser denominadas como 'população tradicional', inseridas agora no contexto de mobilização e criação da Reserva Extrativista TapajósArapiuns. Essa mobilização iniciou-se em meados da década de 1990, com a retomada da luta contra as duas madeireiras que exploravam seus territórios desde os anos de 1980.

Conforme indicado, naquele período inicial fora pactuado um acordo com essas empresas, estabelecendo que elas somente poderiam explorar madeira acima do limite dos 13,4 quilômetros além da margem do rio. No entanto, em meados da década de 1990 as empresas madeireiras começaram a desrespeitar o acordo, avançando além dos limites fixados. Comunidades localizadas tanto na margem esquerda do Rio Tapajós quanto na margem direita do Rio Arapiuns começaram a se mobilizar para impedir tais avanços. Naquele momento, embora empreendendo essa resistência, as comunidades de ambos os rios desconheciam a luta que cada uma delas estava travando contra as respectivas empresas. O conhecimento só ocorreu em finais de 1996, promovido pelo Grupo de Defesa da Amazônia 
(GDA), que atuava com algumas dessas comunidades. Quando aconteceu, os seus representantes não hesitaram em unir forças e propuseram a criação de uma Reserva Extrativista que abarcasse as terras de ambos os lados (Tapajós e Arapiuns). Pretendiam, assim, retirar definitivamente as empresas madeireiras de seus territórios, "fazer uma varredura", como expressou um de seus líderes:

Tinha esta briga dos nossos parentes lá no Tapajós com a empresa madeireira, e a gente aqui no Arapiuns brigava com outra. Era uma briga dividida: eles brigavam lá pelos treze quilômetros, e a gente brigava aqui pelos treze também. Só que ninguém tinha conhecimento da luta do outro lado. Quando a gente descobriu que as duas regióes estavam brigando com o mesmo objetivo, foi que se entrosaram, conversaram, $e$ decidiram, então, que não ia ser só os treze quilômetros, que nós ia fazer o seguinte: nós vamos fazer uma varredura total.

A mobilização para a criação de uma reserva extrativista envolveu a formação de duas entidades para representar seus interesses e conduzir suas reivindicações, as quais foram criadas em fevereiro de 1997. A primeira, Associação Intercomunitária Yané Caeté ("Nossa Floresta", em Nheengatu), envolvendo três comunidades na área do Tapajós, Pinhél, Camarão e Escrivão, localizadas ao sul dos limites atuais da Resex Tapajós-Arapiuns. A segunda, Associação Intercomunitária dos rios Aruã, Maró e Arapiuns (AIRAMA), envolvendo as comunidades que se encontram ao longo dos rios Aruã, Maró e Arapiuns. A proposta inicial de área para a Reserva Extrativista abarcava também a extensão de terras que se encontra entre a cabeceira do Rio Arapiuns e as margens dos rios Aruã e Maró, que compõe a Gleba Nova Olinda e se encontra sob jurisdição do Instituto de Terras do Pará (ITERPA); assim como a extensão de terras que se encontra ao longo da margem esquerda do Rio Arapiuns, que compõe a Gleba Lago Grande, atualmente sob jurisdição do INCRA.

Através daquelas duas associações, as comunidades do baixo Tapajós promoveram suas principais formas de articulação para a criação da Resex Tapajós-Arapiuns, o que ocorreu em um período extremamente curto. Pouco mais de um ano após o surgimento des- 
sas associações, a Reserva Extrativista Tapajós-Arapiuns foi oficialmente criada. O Decreto, assinado em 11 de novembro de 1998, delimitou uma área de aproximadamente 647 mil hectares, abrangendo os municípios de Santarém e Aveiro. A área da Resex TapajósArapiuns abarcou as terras circundadas pela margem esquerda do Rio Tapajós e pela margem direita dos rios Arapiuns e Maró, em seus limites leste, norte e oeste, respectivamente. O limite sul foi fixado por uma linha seca que vai do Rio Tapajós ao Rio Maró, na altura da comunidade de Escrivão. Esse limite, no entanto, deixou de fora a sede da comunidade de Escrivão, uma das três comunidades que iniciaram o movimento para a criação da Reserva Extrativista, e incluiu apenas as áreas de roçado. Além da sede da comunidade de Escrivão, também foram excluídas dos limites da Resex Tapajós-Arapiuns as terras das comunidades localizadas na Gleba Nova Olinda e na Gleba Lago Grande.

Ainda assim, a área que compreendeu a Resex Tapajós-Arapiuns contemplou cerca de 20 mil pessoas, as quais se encontram distribuídas por 67 comunidades. Embora o processo de regulamentação ainda não esteja concluído, a criação da Resex Tapajós-Arapiuns assegurou a retirada das duas madeireiras da área e o fim da exploração comercial de madeira no interior de seus limites. Logo depois que a Reserva Extrativista foi criada, as empresas foram obrigadas a paralisar suas atividades e a retirar seus equipamentos da área. As ameaças ao padrão de ocupação da terra que essas empresas representavam foram, enfim, afastadas. Depois de reconhecê-las como 'população extrativista tradicional', o Estado garantiu-lhes o direito sobre as terras.

Populações tradicionais e direitos territoriais: na década de 1990 as comunidades do baixo Rio Tapajós enfrentaram um segundo momento em relação às formas de identificação e à luta pelo acesso e pelo domínio de suas terras. Por movimentos distintos, as comunidades de ambas as margens do rio tornaram-se igualmente identificadas como 'populações tradicionais' e lhes foram assegurados direitos territoriais, os quais estavam fortemente ameaçados desde finais da década de 1970. Na Flona Tapajós as comunidades tiveram que resistir por mais de duas décadas para ter os direitos reconheci- 
dos e evitar definitivamente a desapropriação de suas terras, como estava inicialmente programado. Daquelas formas de identificação prévias, como 'posseiros, ocupantes ocasionais', que retiravam ou desqualificavam qualquer vínculo mais sólido que as pessoas poderiam ter em relação à terra, ou de pertencimento a uma organização social mais ampla, elas passam a ser reconhecidas como detentoras de uma 'tradicionalidade' e com direitos territoriais oficialmente assegurados.

Essa nova conformação, como analisa Esterci (2002) para toda a Amazônia, reflete o processo de redefinição e reclassificação dos segmentos sociais que passou a ocorrer naquele período, determinado pela inclusão de critérios ecológicos. A incorporação da dimensão ambiental às identidades sociais conferiu maior legitimidade às reivindicações por direitos territoriais. No baixo Tapajós esse processo se conformou simultaneamente com a redefinição dos espaços (seja pela criação da Reserva Extrativista, seja pela aceitação da permanência das populações na Flona) e com a redefinição das regras de uso e de acesso aos recursos naturais.

É precisamente nessa convergência que as pessoas das comunidades em ambas as reservas enfrentaram o terceiro dilema em relação aos territórios e às formas de identificação. Para elas, a mudança na legislação, assim como a criação da Reserva Extrativista, significou reconhecimento de direitos territoriais, mas também indicou que os modos de uso da terra e de exploração dos recursos estariam, a partir de então, condicionados às regulamentações das reservas, embora sua concepção e controle fossem gerados externamente às suas instituições socioculturais. É desse enfrentamento que veremos despertar o movimento indígena.

\section{Reafirmação étnica e cultural: indígenas em reservas ambientais}

Encerrando a década de 1990, encontraremos um terceiro movimento em relação às identidades e aos espaços territoriais entre as populações nativas no baixo Tapajós. Assim, na virada para o século $\mathrm{XXI}$, ao mesmo tempo que esforços governamentais eram empreen- 
didos tanto para regulamentar e efetivar as mudanças na área da Flona Tapajós (admitindo as 'populações tradicionais' decorrentes da nova legislação das Florestas Nacionais) quanto para implementar a recém-criada Resex Tapajós-Arapiuns, grupos de comunidades em ambas as reservas começaram um movimento de reelaboração de antigas tradições culturais e a se identificar como pertencentes a várias etnias, muitas já consideradas extintas. Como indicado, o movimento inicial foi precipitado pelos indígenas da comunidade de Taquara, na área da Flona Tapajós, seguido logo depois pelas comunidades de Bragança e Marituba.

Atravessando o Rio Tapajós, esse movimento de reafirmação das identidades indígenas envolveu também vários grupos de comunidades na área da Resex Tapajós-Arapiuns, assim como grupos na margem esquerda do Rio Arapiuns e seus afluentes. Mobilizando uma população estimada em 2,5 mil pessoas, o movimento está remodelando a composição sociocultural na região do baixo Tapajós, as formas associativas de organização política, assim como os espaços territoriais dos quais as 'terras indígenas' também passaram a fazer parte.

Apesar do envolvimento de vários grupos na região, o foco de análise continua sobre o movimento de emergência étnica entre os que se encontram nas áreas das duas reservas, a Flona Tapajós e a Resex Tapajós-Arapiuns. É importante, contudo, ter presente a referência da amplitude daquele movimento, pois esses grupos mantêm estreita relação entre si, influenciando-se mutuamente, em especial em suas formas de articulação e organização política, cujas reivindicações são conduzidas em conjunto. Em 2000, depois da participação da Marcha dos 500 Anos para Porto Seguro, os indígenas criaram o Conselho Indígena dos Rios Tapajós e Arapiuns (CITA), que mobiliza todos os indígenas do baixo Tapajós e constitui sua principal representação política.

Indígenas na Flona Tapajós: enquanto a administração da Flona Tapajós envidava esforços para efetivar as mudanças para incorporação daqueles grupos que passaram a ser reconhecidos como 'populações tradicionais', representantes da comunidade de Taquara 
tomavam o rumo do alto Tapajós, em 1998, em busca da sede da Administração Regional da FUNAI, em Itaituba. Naquela visita eles entregaram um documento ao administrador regional solicitando esclarecimentos sobre o direito de validar suas terras como 'área indígena', pois essas se encontravam localizadas dentro da Flona Tapajós. Dias depois o administrador regional da FUNAI visitou os indígenas em Taquara e encaminhou solicitações à Diretoria de Assuntos Fundiários da FUNAI, em Brasília, advogando a formação de um grupo de trabalho para realizar estudos antropológicos, com o objetivo de proceder à regularização daquelas terras. Também enviou ofícios ao IBAMA, ao INCRA e ao Ministério Público informando a existência desses indígenas e dos procedimentos que estavam sendo tomados pelo órgão indigenista (Almeida, 2001).

Essa busca à administração da FUNAI ocorreu poucos meses após a morte do pajé Laurelino, patriarca do maior núcleo familiar de Taquara e principal liderança político-religiosa da comunidade. Após a sua morte, ${ }^{14}$ ocorrida em maio de 1998, os indígenas em Taquara iniciaram esse processo de reelaboração cultural, retomando manifestações rituais, língua (Nheengatu), pinturas corporais, e passaram a reconhecer pertencimentos à etnia Mundurucu. Vários eventos marcaram o início desse processo de reafirmação da identidade indígena em Taquara. Em outubro, durante os festejos da Nossa Senhora Aparecida, eles promoveram uma "Missa Indígena" e, na virada do ano para 1999, organizaram o "Primeiro Encontro Indígena". Dos dois eventos participaram representantes de várias comunidades do Tapajós e Arapiuns, de órgãos governamentais e de apoio ao movimento popular. Durante o Encontro foi cravado um mastro no centro da aldeia como marca desse momento do grupo, que se conformava pela autopercepção de sua identidade étnica.

Esse movimento dos indígenas de Taquara foi seguido logo depois pelos de Marituba e Bragança, que acompanharam as discussões e mobilizações iniciais e igualmente passaram a se reconhecer como pertencentes à etnia Mundurucu. No contexto da Flona Tapajós, essas três comunidades conformaram uma nova unidade sociocultural que foi se distinguindo daqueles demais grupos en- 
contrados na área da reserva florestal e que passaram a ser reconhecidos como 'populações tradicionais. Reivindicando pertencimento a uma coletividade etnicamente organizada, essas três comunidades se distanciaram daqueles grupos com os quais haviam compartilhado um histórico de lutas em defesa de suas terras, gerando uma cisão entre elas, entre os indígenas e não indígenas, mais precisamente entre 'indígenas' e 'populações tradicionais'. Conformando, portanto, dois grupos cultural e politicamente organizados na área da Flona Tapajós, a cisão que se estabeleceu entre esses dois grupos sociais distingue-os em suas formas de identificação, de organização sociocultural e política, e, principalmente, em suas reivindicações pela regularização da terra.

Nessa nova conformação eles também romperam relações com a administração da Flona Tapajós, recusando-se a participar de qualquer negociação ou atividade promovida pelos representantes da reserva. Desde que souberam pelo administrador regional da FUNAI que tinham direito ao reconhecimento oficial de suas terras, os indígenas passaram a reivindicar a sua regularização junto à DAF/FUNAI. Em resposta às reivindicações, a FUNAI criou, em finais de janeiro de 2001, um grupo técnico de trabalho (GT) para a realização de levantamentos sobre os indígenas no baixo Tapajós. Esse GT visitou os índios Mundurucus de Taquara, Bragança e Marituba, e algumas comunidades indígenas localizadas na área da Reserva Extrativista Tapajós-Arapiuns, onde não chegou a terminar as atividades. Ressaltando a legitimidade da reivindicação dos indígenas pelo reconhecimento de suas terras, o relatório final dessa equipe de trabalho sugeriu a continuidade dos levantamentos entre os indígenas na área da Resex Tapajós-Arapiuns e a criação de um GT para estudos de identificação e delimitação das 'terras indígenas' de Taquara, Marituba e Bragança (Almeida, 2001). Os estudos para identificação e delimitação das terras desses indígenas foram conduzidos no segundo semestre de 2003 e apresentaram proposta de criação de duas Terras Indígenas: T.I. Munduruku-Taquara e T.I. Bragança-Marituba (Ioris, 2008).

Além desses procedimentos para reconhecimento oficial das terras pelo governo federal, destacam-se também algumas iniciati- 
vas implantadas pelo poder público local. No município de Belterra essas atenções se refletiram no ordenamento e nas ações do seu Plano Diretor Participativo, elaborado durante o ano de 2006 e sancionado em fevereiro de 2007 (Lei $\mathrm{n}^{\circ}$ 131). Com a participação de representantes indígenas nos trabalhos de elaboração, o Plano Diretor estabeleceu, no artigo 37, que as terras dos índios Mundurucu de Bragança, Marituba e Taquara configuram "Zonas Especiais de Interesse Cultural". Nesse contexto, a Prefeitura Municipal criou ainda a Coordenação Indígena, alocada na Secretaria de Planejamento e Gestão, para tratar exclusivamente dos interesses dos indígenas do município. Além disso, as escolas de ensino fundamental em Bragança, Marituba e Taquara passaram a ser reconhecidas como 'escolas indígenas' e seguem, em princípio, um ensino diferenciado.

Foi também nesse contexto que os indígenas criaram o Conselho Indígena Mundurucu de Belterra (CIMB), efetivado em dezembro de 2007, durante a Festa da Many, ${ }^{15}$ que ocorre todos os anos entre os Mundurucu de Taquara. Assim, mobilizados em reafirmar sua identidade étnica, os indígenas de Taquara, Bragança e Marituba renegaram a atribuição de 'população tradicional', decorrente da nova legislação do SNUC, assim como o modelo de ocupação de terra que lhes foi outorgado na condição de residentes em uma área de Floresta Nacional. Reafirmando-se como Mundurucu, eles têm se distinguido cultural e politicamente, e reiterado a reivindicação pela regularização de suas terras, que deverão, para tal, ser excluídas dos limites da Flona Tapajós, assegurando-lhes o usufruto exclusivo.

Indígenas na Resex Tapajós-Arapiuns: semelhante ao que ocorria na Flona Tapajós, onde o movimento de reafirmação étnica e cultural começou logo depois de estabelecidas mudanças na legislação para admitir a permanência das 'populações tradicionais', na Resex Tapajós-Arapiuns o movimento acompanhou o processo de implementação, iniciado imediatamente após a criação. Assim, enquanto medidas governamentais eram tomadas para regularização e operacionalização dessa Reserva Extrativista, vários grupos de comunidades igualmente iniciavam um movimento de reafirmação de suas tradições e raízes étnicas e culturais. Um ano após a criação da 
Reserva Extrativista, diversas comunidades passaram a se identificar como pertencentes a diferentes etnias, tais como Arapium, Tupaiú, Maytapu, Kumaruara, Tupinambá, Cara-Preta e Arara Vermelha. A grande maioria dos líderes dessas comunidades indígenas esteve fortemente engajada na mobilização para a criação da Resex Tapajós-Arapiuns.

Inicialmente essas comunidades sofreram influências do movimento que ocorria em Taquara, onde participaram em algumas celebrações rituais. Como explicava o indígena de Santo Amaro, "nós começamos o nosso movimento indígena aqui pela reunião lá no Taquara. Nós fomos lá e quando nós viemos nós decidimos formar nossa aldeia aqui no Santo Amaro". O entusiasmo pelos encontros em Taquara motivou uma sequência de vários outros, realizados anualmente em diferentes locais no Tapajós e no Arapiuns, ${ }^{16}$ em comunidades na área da Resex Tapajós-Arapiuns e fora dela. Realizados sempre na virada de ano, esses eventos foram denominados de "Encontros de Reconhecimento Indígena". Em todos eles os indígenas reproduziram o ritual de cravar um mastro no centro da comunidade anfitriã, como símbolo da identidade étnica que passavam a reconhecer.

Assim, influenciadas pelo processo de reafirmação étnica que estava ocorrendo em Taquara, várias outras comunidades também passaram a se reconhecer como parte de etnias que, até então, eram consideradas extintas, e, desse modo, têm ajudado a moldar uma nova composição sociocultural no baixo Tapajós. Em 2001, quando a FUNAI realizou o primeiro levantamento das demandas indígenas na área da Resex Tapajós-Arapiuns, a equipe do GT identificou 13 comunidades somente na área do Rio Tapajós. Atualmente, os indígenas se encontram em 21 comunidades, entre as quais identificam sete etnias. A força que desencadeou o movimento indígena no baixo Tapajós e o fez alastrar-se por uma vasta extensão constitui fenômeno ainda difícil de avaliar em sua plenitude. Conformou um movimento intenso e rápido que envolveu muitos grupos de comunidades, inclusive algumas que posteriormente recuaram do processo. Mas, no momento inicial, tomou forte impulso, com capacidade de fazer com que Livaldo Sarmento da Silva, da comunidade de São Pedro, na área Resex Tapajós-Arapiuns, se candidatasse e se elegesse em 2000 como o 'primeiro vereador indígena' do município de Santarém. 
Naquele momento inicial os representantes do movimento indígena e da Resex Tapajós-Arapiuns atuavam conjuntamente. Na primeira diretoria da Reserva Extrativista havia dois indígenas, o seu presidente, da comunidade de Suruacá, que se reconhecia como índio Kumaruara, assim como a secretária de finanças, da comunidade de Escrivão, que se reconhecia como Cara-Preta. Ambos os diretores foram atuantes tanto no movimento para a criação da Reserva Extrativista quanto na organização do movimento indígena.

No momento seguinte, no entanto, o movimento indígena sofreu um recuo e o vereador eleito assim como algumas comunidades, ou partes delas, retrocederam e passaram a renegar sua identificação como indígena ${ }^{17}$. Enquanto parcela dessa população que inicialmente se engajou no movimento indígena retrocedia, outra, contudo, reafirmava e renovava os laços com as suas origens étnicas. Este grupo, desde então, tem se mobilizado na reconstrução de suas identidades étnicas, de suas formas de organização e representação política, e nas demandas pela regularização das terras indígenas. Análogo ao que ocorreu entre os indígenas na Flona Tapajós, traçando um horizonte étnico, este grupo foi trilhando um caminho separado daqueles que haviam sido parceiros em vários momentos de suas vidas e de luta pela terra. Essas diferenças também conformaram dois grupos sociais distintos na Reserva Extrativista Tapajós-Arapiuns, indígenas e não indígenas, ou 'populações tradicionais' e 'indígenas', com formas de organização e representação políticas próprias.

As diferenças que se conformaram entre os dois grupos levaram a conflitos de diversas ordens entre eles, posicionando-os em arenas distintas, especialmente em relação à questão fundiária. Reivindicando a regularização das terras, os indígenas têm enfrentado forte resistência dos grupos não indígenas, que reclamam que a demarcação de uma 'terra indígena' ameaçará a integridade da Reserva Extrativista e das vitórias que ela significa na luta pela posse da terra. No contexto dessas disputas, a FUNAI pouco avançou para a resolução da questão fundiária dos indígenas. Desde 2001 o órgão indigenista enviou sete grupos técnicos de trabalho para levantamentos de informações e das demandas indígenas na Resex Tapajós-Arapiuns. 
Porém, até o momento, não elaborou nenhuma proposta de área ${ }^{18}$ para eles. Entre o poder público local algumas atenções aos indígenas têm sido dedicadas, especialmente em relação à educação, a qual é conduzida pela Secretaria de Educação da Prefeitura de Santarém, através do Departamento de Educação Escolar Indígena, criado em 2006, para promover uma educação diferenciada entre esses grupos.

Não obstante esses procedimentos oficiais de reconhecimento aos direitos indígenas sobre suas terras, ainda é incerto o alcance que eles poderão esperar na sua regularização. Os indígenas, articulados em torno de sete etnias, têm mantido ao longo de uma década uma organização sociopolítica e cultural distinta. Reafirmando suas identidades étnicas, eles também têm renegado a atribuição de 'população tradicional', que resultou da criação da Resex TapajósArapiuns, assim como o modelo de gestão que essa categoria de reserva impõe sobre suas terras, reivindicando o reconhecimento da área como 'terra indígena'. Buscam, como se verá a seguir, assegurar não só o usufruto exclusivo, mas também definitivo da terra.

\section{Identidades étnicas e a busca por autonomia sobre a ter-}

ra: abordamos neste item o movimento de reafirmação étnica e cultural que começou a ocorrer em finais da década de 1990 entre grupos de comunidades no interior da Flona Tapajós e da Resex TapajósArapiuns. Em ambas as situações o movimento iniciou-se quando, aparentemente, comemoravam vitória sobre uma longa disputa pelas terras que ocupavam: de um lado, para evitar a expulsão da área onde foi criada a Flona; de outro, contra as empresas madeireiras, que insistiam em avançar sobre os territórios nativos. Foi precisamente quando, no caso da Flona Tapajós, a legislação mudou e admitiu que essas populações permanecessem em suas terras e, no caso da Reserva Extrativista, as madeireiras afastadas que esses grupos de comunidades iniciaram esse processo de retomada de antigas tradições culturais e passaram a se reconhecer como portadoras de identidades étnicas diferenciadas, reivindicando a regularização de suas terras junto à FUNAI. Foi somente quando passaram a ser identificados como 'populações tradicionais' que esses grupos deram um passo adiante e, contrapondo-se à definição oficialmente atribuída, mostraram a feição que pretendiam dar a essa categoria. 
Em estudo anterior, sobre a emergência do movimento de reafirmação étnica entre os indígenas na Flona Tapajós, demonstrou-se de que forma esse configurou resistência à noção de 'população tradicional', atribuída em decorrência da mudança da legislação relativa às Florestas Nacionais (Ioris, 2005). Uma noção, como vários autores assinalaram, forjada no debate ambientalista internacional sobre a presença de grupos humanos em áreas de conservação ambiental (Almeida, 2001; Barretto, 2001; Cunha e Diegues, 1998; Lima, 2002; Vianna, 1996). Acompanhando a problemática no Brasil, especialmente em relação ao advento das reservas extrativistas, a adoção daquele conceito ocorreu a partir da década de 1990, designando grupos sociais específicos e distintos entre si, mas que estavam desprovidos de reconhecimento legal que garantisse direitos sobre as terras que historicamente habitavam. Nesse sentido, Barretto (2001, p. 1) destaca a ambivalência da noção,

[...] pois, ao mesmo tempo em que opera como categoria residual de sentido negativo, abrangendo tudo o que não é índio, nem quilombola, nem seringueiro, abarca e compreende todas estas categorias e outras mais de grupos sociais cuja distintividade cultural se expressaria em termos de territorialidades específicas.

Oficialmente, a expressão 'população tradicional' foi usada pela primeira vez com a criação do CNPT, em 1992. Mas uma definição somente foi elaborada posteriormente, durante os trabalhos para sua incorporação ao novo SNUC, aprovado em 2000, visando compreender e regularizar as situações dos grupos populacionais em áreas de reservas ambientais, que passaram a ser qualificadas como 'unidades de conservação de uso sustentável' ${ }^{19}$. Frente à agência ambientalista governamental, a incorporação das 'populações tradicionais' expressou uma mudança significativa na concepção e, no campo de ação de reservas ambientais, nas quais, até então, estava interditada qualquer forma de ocupação humana, razão dos longos conflitos com as populações no interior da Flona Tapajós.

A definição de 'população tradicional' na atual versão do SNUC encontra-se, porém, diluída entre os artigos que definem e regula- 
mentam as respectivas reservas. Ela não está, por exemplo, incisa no artigo referente às Florestas Nacionais, que passou a admitir a permanência delas, mas está presente no artigo que se refere às Reservas de Desenvolvimento Sustentável. Para estas (Artigo 18), definese como 'população tradicional' aquelas

[...] cuja existência baseia-se em sistemas sustentáveis de exploração dos recursos naturais, desenvolvidos ao longo de gerações e adaptados às condições ecológicas locais e que desempenham um papel fundamental na proteção da natureza e na manutenção da diversidade biológica.

No artigo sobre as Reservas Extrativistas (Artigo 20) aparece a definição de "populações extrativistas tradicionais", definidas como aquelas "cuja subsistência baseia-se no extrativismo e, complementarmente, na agricultura de subsistência e na criação de animais de pequeno porte".

Como se vê, em ambas as definições a noção de 'população tradicional' oficialmente adotada está fortemente vinculada a critérios ecológicos, de sustentabilidade ambiental e não socioculturais, levando a comprometer as formas particulares de identificação e de organização dos espaços e da apropriação dos recursos. Assim, subjugando as formas grupos se organizarem e se relacionarem com os recursos naturais a parâmetros alheios ao seu universo sociocultural, essa noção, como assinalou Barretto (2001), conspira contra a sua autonomia, pois condiciona seu futuro a uma racionalidade de política florestal que lhes é exógena.

Essa perspectiva é especialmente relevante em relação às Florestas Nacionais, cuja regulamentação recente, ao admitir a presença das populações tradicionais, reforça os mecanismos que anulam a autonomia dos grupos sociais sobre suas terras. Isso se reflete, por exemplo, na maneira como passou a contemplar essas populações nas áreas das reservas. Nela não há um reconhecimento dos direitos dessas populações sobre as terras que historicamente ocupam, mas uma 'admissão' à sua permanência nelas. Assim se estabelece a priori uma relação de dependência e poder desigual que neutraliza a legitimidade das reivindicações desses grupos sociais sobre os territórios e 
os recursos que utilizam. Além disso, a legislação também estabelece que essa permanência deva ocorrer em "conformidade com o plano de manejo da reserva". No entanto, considerando que os objetivos dos planos de manejo das Florestas Nacionais é a exploração florestal para produção comercial de madeira, essa conformidade implica ajustar as formas de organização e apropriação dos recursos das 'populações tradicionais' aos critérios e objetivos estabelecidos para a reserva, os quais estão centrados na promoção da exploração madeireira. Como destaca Almeida (2004, p. 10),

O fato de o governo ter incorporado a expressão 'populações tradicionais' na legislação competente e nos aparatos burocrático-administrativos... não significa exatamente um acatamento absoluto das reivindicações encaminhadas por estes movimentos sociais, não significando, portanto, uma resolução dos conflitos e tensões em torno daquelas formas intrínsecas de apropriação e de uso comum dos recursos naturais...

Foi, portanto, reagindo a essa forma de identificação, que simplifica uma diversidade das situações culturais, naturalizando os grupos sociais para estabelecer uma relação instrumental que responda aos objetivos dos planos de manejo das reservas ambientais, que se vislumbrou a emergência desse movimento de reafirmação das identidades étnicas entre os indígenas na área da Flona Tapajós (Ioris 2005, 2006). Como se demonstrou, não era apenas para permanecer em suas terras que esses grupos haviam se engajado em várias formas de luta, mas também para exercitar um modo de vida particular que a categorização de 'população tradicional' definida na nova versão do SNUC tende a subtrair.

As investigações seguintes indicaram que na área da Resex Tapajós-Arapiuns a principal motivação externa para a emergência do movimento étnico também constitui uma reação à categoria de 'população tradicional' e às inferências que lhes são decorrentes no modo de uso da terra. De forma geral, os indígenas têm apresentado forte reação a esse modelo de reserva que abarcou suas terras. São recorrentes os argumentos de que, ao lutarem pela criação da Reserva Extrativista, acreditavam estar assegurando o domínio sobre seus 
territórios e modos de vida, mas que, depois de criada, descobriram que essa não correspondia aos seus intentos. Esse desapontamento era especialmente referente ao termo de concessão de uso, que regulariza a permanência das populações residentes nas reservas extrativistas. Nessa direção, os indígenas reconhecem estreita relação entre a emergência do movimento de reafirmação de identidades étnicas e o conhecimento de que nas reservas extrativistas não é concedido título definitivo da terra aos seus moradores, mas de que esse deverá ser renovado periodicamente.

Nas reservas extrativistas não é assegurada às populações a posse permanente da terra. A sua permanência é regulamentada através do título de concessão de uso, que varia entre 30 e 40 anos, podendo ser renovado. Esse título de concessão de uso não é repassado individualmente, mas para as associações que representam as populações, que poderá ser somente uma, englobando todas as pessoas e grupos da Reserva Extrativista, ou para várias associações de abrangência menor, envolvendo grupos distintos, quando elas existirem. A orientação é de que as próprias populações decidam através de quais associações querem ser representadas.

O conhecimento de que a permanência na área de Reserva Extrativista estaria condicionada a um termo de concessão de uso com tempo determinado frustrou as metas da luta que empreendiam para um domínio exclusivo e definitivo sobre suas terras. Como expressou o indígena Frediano, "aqui ninguém sabia, não tinha, assim, um esclarecimento certo... Ninguém tava sabendo que era só definida pra trinta anos". Frustrou-lhes o entendimento de que a criação da Reserva Extrativista Tapajós-Arapiuns significava apenas uma segurança transitória na luta pela terra.

A grande maioria das lideranças indígenas da Resex TapajósArapiuns também capitaneou o movimento para a criação dessa Reserva Extrativista, que, por sua vez, visava à expulsão das empresas madeireiras. Muitas dessas lideranças já estavam à frente do movimento contra as madeireiras desde o início da década de 1980. A luta que travaram ao longo dos anos era, portanto, para afastar as madeireiras do controle sobre as terras e para retomar o acesso e, o domínio que originalmente detinham sobre elas, das quais foram priva- 
dos em decorrência da ação daquelas empresas. Acreditavam que a criação da Reserva Extrativista encerraria uma disputa pelo domínio exclusivo de suas terras, tornando inquestionáveis e infindáveis o seu direito de posse e o dos seus descendentes.

Do mesmo modo que os indígenas na área da Flona Tapajós, os indígenas na área da Resex Tapajós-Arapiuns também demonstram que o engajamento nas lutas em defesa de seus territórios visava não só à posse das terras, mas tinha por objetivo assegurar um modo de vida particular e de ocupação dos espaços. Visava, sobretudo, a uma autonomia sobre os territórios que a categoria de 'população tradicional' tende a renegar. Tanto numa reserva quanto na outra, os indígenas perceberam que era preciso cavar mais profundamente a raiz da sua história para tentar, assim, assegurar a autonomia que almejavam e pela qual lutavam em seus territórios.

\section{Conclusão}

Em texto recente, Bartolomé (2006) discute os distintos conceitos de etnogênese que a literatura antropológica tem elaborado para examinar os processos de reconstrução dos grupos sociais como coletividades etnicamente articuladas e culturalmente diferenciadas. Destacando as etnogêneses como processos que sempre estiveram presentes na história da humanidade, o autor assinala que elas constituem "o processo básico de configuração e estruturação da diversidade cultural humana" (p. 2). Adianta-se, assim, em responder às reações de surpresa manifestadas por alguns pesquisadores frente aos movimentos que recentemente têm se evidenciado, afirmando que "a etnogênese é parte constitutiva do próprio processo histórico da humanidade e não só um dado do presente" (p. 3).

Em relação aos indígenas do baixo Tapajós essa dimensão encontra-se constantemente presente. Nesse sentido, do ponto de vista histórico, o atual movimento de reconstrução étnica e cultural entre os grupos daquela região não constitui fenômeno incomum entre as suas populações nativas. Até onde os registros históricos permitem lançar um olhar sobre a ocupação da região, observam-se ao longo do tempo sucessivos processos de reconstrução das organizações 
sociais nativas, especialmente em resposta aos efeitos dos avanços da empresa colonial. O movimento atual de reelaboração étnica e cultural oferece o privilégio de ser acompanhado in loco, facilitando apreender os elementos motivadores e constitutivos desse processo de reconstrução das antigas referências culturais e das identidades indígenas. Ele tem mostrado sua dinâmica inserida em um jogo de disputas sobre os domínios identitários e territoriais, o qual se conformou frente aos novos interesses econômicos e geopolíticos que se instalaram na região e avançavam sobre os territórios nativos. As disputas sobre as identidades dos grupos sociais nas áreas das duas reservas ambientais eram simultaneamente disputas que se processavam sobre a posse e o controle de seus territórios.

Em tais contextos, as disputas conformavam um sentido semelhante ao assinalado por Bourdieu (2003, p. 221) sobre as lutas a respeito das identidades étnicas ou regionais, no qual destaca que elas constituem "lutas pelo monopólio de fazer ver e fazer crer, de dar a conhecer e de fazer reconhecer, de impor a definição legítima das divisões do mundo social, e, por este meio, de fazer e de desfazer os grupos". Ao pousar um olhar sobre o fenômeno recente das etnogêneses no baixo Tapajós, encontra-se a sua emergência encravada em disputas por esses 'monopólios', cujos sentidos constituíram-se nos confrontos sobre o acesso e, o controle dos domínios territoriais. Através dessas várias arenas de lutas que se configuraram deparamo-nos novamente com o entendimento, já bastante discutido na perspectiva do construtivismo social dos estudos antropológicos, de que a busca por um "objeto definitivo e coerente é uma fantasia, e que identidade pessoal ou coletiva é [sempre] social, precária e constantemente reconstruída" (Haraway, 1991, p. 148).

\section{Notas}

${ }^{1}$ A região do baixo Rio Tapajós está localizada no sudoeste do estado do Pará, numa área categorizada pelo IBGE como microrregião do Médio Amazonas Paraense, mais comumente conhecida como Baixo Amazonas.

${ }^{2}$ O Projeto RETER, conduzido nos anos de 2007 e 2008, foi beneficiário da bolsa de PósDoutorado Junior (PDJ), do Conselho Nacional de Desenvolvimento Científico e Tecnológico (CNPq), e vinculado ao Departamento de Antropologia da Universidade de Brasília (DAN). 
${ }^{3}$ No baixo Tapajós os jesuítas fundaram cinco Missões, em diferentes locais: 1) em 1661, a Missão Tapajó, em frente à foz do Tapajós, onde hoje se encontra a cidade de Santarém; 2 ) em 1723, a Missão Tapajó foi transferida para a região do Rio Arapiuns, sob o nome de Missão de Nossa Senhora da Assunção dos Arapiuns, atual Vila Franca; 3 ) em 1722, a Missão de São José dos Maytapú, atual Pinhél, na margem esquerda do Tapajós, a 180 km ao sul de Santarém; 4) em 1723, a Missão de Iburari, ou Borary, atual Alter do Chão, na margem direita do Tapajós; e 5) em 1740, a Missão de Santo Inácio ou dos Tupinambaranas, atual Vila de Boim, na margem esquerda do Tapajós. Com exceção de Alter do Chão e Santarém, todos os demais locais se encontram no interior dos limites da Resex Tapajós-Arapiuns (ver Figura 1).

${ }^{4}$ Às vezes os indígenas referem-se indistintamente à 'Guerra da Cabanagem' e à 'Guerra do Paraguai', usadas indistintamente. Da Amazônia foram enviados 2.070 homens para a Guerra do Paraguai (Moreira Neto, 1971), sendo que centenas de indígenas foram compulsoriamente arregimentados, como testemunhou o casal Luis e Elizabeth Agassis ( 1975). Porém, no momento não nos é possível abordar com mais detalhes a questão da Guerra do Paraguai e sua importância para a região do baixo Tapajós, pois ainda não se encontram dados disponíveis que sejam específicos para esta região. Tais informações poderiam ajudar a elucidar a importância dessa arregimentação forçada dos indígenas para lutar na Guerra do Paraguai, tendo em vista a aceleração do processo de interiorização motivado pelas fugas, o qual já estava em curso por conta dos confrontos da Cabanagem.

${ }^{5}$ Diferentemente de outras regiões da Amazônia, a economia da borracha que se desenvolveu no baixo Tapajós era baseada nas seringueiras de cultivo, e não nas nativas, as quais já eram previamente cultivadas pelos indígenas. O desenvolvimento daquela economia intensificou as relações comerciais e ajudou a trazer essas populações de volta às áreas localizadas na beira do rio. Segundo relatos, a fixação teria ocorrido gradualmente. Por um longo período os núcleos domésticos alternavam as ocupações das áreas de beira e de mata, durante o período das chuvas no centro da mata, e durante a estiagem na beira. Apesar do movimento para as áreas de beira, as antigas moradias no centro da mata foram mantidas e tornaram-se a principal unidade produtiva, as quais denominam colônias ou sítios. Assim, embora influenciando a dinâmica do padrão de organização produtiva e ocupação da terra dos indígenas, a economia da borracha não produziu alterações significativas em sua estrutura ou comprometeu a autonomia sobre a produção. A respeito do desenvolvimento da economia da borracha no baixo Tapajós, ver Costa (1993).

${ }^{6}$ Em sua discussão sobre os processos de etnogêneses no Nordeste do Brasil, Oliveira (1999, p. 28) destaca ainda que o atributo da invisibilidade, "embora possa ser de utilidade como artifício descritivo, no plano da análise comparativa continua a ser caudatária de uma etnologia das pardas e das ausências culturais"; a mesma à que Nugent (1993) busca se opor.

${ }^{7}$ Organização das Nações Unidas para a Alimentação e Agricultura (FAO).

${ }^{8}$ Sobre os trabalhos desenvolvidos através das CEBs e sua importância na conformação das "comunidades" no baixo Amazonas, ver Lima (1999) e Lins e Silva (1980).

${ }^{9}$ Atualmente a área da Flona Tapajós pertence ao município de Belterra, criado em 1996, cuja área foi subtraída do município de Santarém.

${ }^{10}$ Comunidades de São Domingos, Maguary, Jamaraquá, Acaratinga, Jaguarary, Pedreira, Piquiatuba, Nazaré, Marai, Tauari, Pini, Prainha, Paraíso, Itapaiuna, Jatoarana e Itapuama.

${ }^{11}$ Instituto Nacional de Colonização e Reforma Agrária (INCRA).

\section{ILHA}

volume 11 - número 2 
${ }^{12}$ Federação de Órgãos para Assistência Social e Educacional (FASE).

${ }^{13}$ Instituto de Manejo e Certificação Florestal e Agrícola (IMAFLORA), uma organização não governamental sediada em Piracicaba, estado de São Paulo.

${ }^{14}$ Para uma análise da importância da morte deste líder como motivação interna para a emergência do movimento de reafirmação étnica cultural entre os indígenas de Taquara, ver Ioris (2005).

${ }^{15}$ A Festa da Many, antiga celebração ao mito de origem da mandioca, foi retomada na última década em decorrência do processo de reafirmação da identidade indígena, tornando-se parte das suas festividades anuais.

${ }^{16} \mathrm{Na}$ virada para o ano 2000 foi realizado o Segundo Encontro Indígena na comunidade de Jaurituba, na margem esquerda do Tapajós, na área da Resex Tapajós-Arapiuns. Essa comunidade juntamente com suas vizinhas imediatas, Santo Amaro, Mirixituba, Muratuba, Jaca e Paraná-Pixuna, passaram a reconhecer pertencimentos à etnia Tupinambá. Os dois encontros seguintes foram realizados no Arapiuns, na comunidade de São Francisco, margem esquerda do Rio Arapiuns, na Gleba Lago Grande e na comunidade de São Pedro, na área da Resex Tapajós-Arapiuns. No início do ano de 2003 o evento retornou para o Tapajós, na comunidade de Bragança; e no início do ano de 2005 foi para o Rio Maró, na comunidade de Novo Lugar, na Gleba Nova Olinda.

${ }^{17}$ Até o momento as investigações sobre este recuo foram realizadas somente entre os indígenas, e não entre os representantes dos grupos que retrocederam, não permitindo, assim, mais afirmações sobre as suas razões, consistindo em tema a ser investigado no futuro.

${ }^{18}$ Em 2001 a FUNAI encaminhou o primeiro grupo de trabalho para levantamento das informações e demandas dos indígenas, cujos trabalhos foram complementados em 2003. Em 2008 a FUNAI encaminhou novamente dois grupos de trabalho ao campo: um para identificação e delimitação das terras dos indígenas Cara-Preta e Maytapú, nas comunidades de Pinhél e Escrivão, ao sul da área da Resex TapajósArapiuns (Portaria n. 952, de 14 de outubro de 2008); e outro para atualizar os levantamentos sobre os demais grupos indígenas na área da Reserva Extrativista e conduzir estudos de fundamentação antropológica sobre os grupos indígenas do baixo Tapajós e Arapiuns, visando subsidiar as ações da FUNAI (Portaria n. 777, de 6 de agosto de 2008).

${ }^{19}$ Na nova versão do SNUC as reservas ambientais foram divididas em dois grupos: as Unidades de Conservação de Proteção Integral e as Unidades de Conservação de Uso Sustentável. No primeiro grupo encontram-se: Estação Ecológica, Reserva Biológica, Parque Nacional, Monumento Natural e Refúgio de Vida Silvestre. No segundo grupo encontram-se: Floresta Nacional, Área de Relevante Interesse EcológiCo, Área de Proteção Ambiental, Reserva Extrativista, Reserva de Fauna, Reserva de Desenvolvimento Sustentável e Reserva Particular do Patrimônio Natural.

\section{Referências}

AGASSIZ, Luis; AGASSIZ, Elizabeth. Viagem ao Brasil: 1865-1866. Belo Horizonte: Itatiaia; São Paulo: Ed. USP, 1975.

ALLEGRETTI, Mary. 2002. A construção social de políticas ambientais: Chico Mendes e o movimento de seringueiros. Tese (Doutorado em Antropologia) Universidade de Brasília, Brasília, 2002.

\section{ILHA}


ALMEIDA, Alfredo Wagner B. Terras de preto, terras de santo, terras de índio: uso comum e conflitos. In: CASTRO, E. M.; HEBETTE, J. (Eds.). Na trilha dos grandes projetos. Belém: NAEADEd. UFPA, 1989. p. 163-196.

. Terras tradicionalmente ocupadas: processos de territorialização e movimentos sociais. Revista Brasileira de Estudos Urbanos e Regionais, v. 6, n. 1, p. 9-32, 2004.

ALMEIDA, Rita H. O diretório dos índios: um projeto de "civilização" no Brasil do século XVIII. Brasília: Ed. UnB, 1997.

. Relatório de viagem ao Rio Tapajós. FUNAI, Portaria n 84/2001. BrasíliaDF, 2001.

ARRUTI, José Maurício A. A emergência dos 'remanescentes': notas para o diálogo entre indígenas e quilombolas. Mana: Estudos de Antropologia Social, Rio de Janeiro: Ed. UFRJ, v. 3, n. 2, p. 7-38, 1997.

BARRETTO, Henyo T. 2001. Da Nação ao planeta através da natureza: uma abordagem antropológica das unidades de conservação de proteção integral na Amazônia brasileira. Tese (Doutorado em Antropologia) - Universidade de São Paulo, São Paulo, 2001a.

. Populações tradicionais: introdução à crítica da ecologia política de uma noção. In: WORKSHOP SOCIEDADES CABOCLAS AMAZÔNICAS: MODERNIDADE E INVISIBILIDADE, 21-24 out. 2001b, Parati-RJ.

BARTH, Fredrik (Ed.). Ethnic Groups and Boundaries: The Social Organization of the Culture Difference. Boston: George Allen \& Unwin, 1970.

BARTOLOMÉ, Meliá A. As etnogêneses: velhos atores e novos papéis no cenário cultural e político. Mana: Estudos de Antropologia Social, Rio de Janeiro: Ed. UFRJ, v. 2, n. 1, p. 39-68, 2006.

BATES, Henry W. Um naturalista no Rio Amazonas. Belo Horizonte: Itatiaia/Ed. USP, 1979.

BECKER, Bertha K. Repensando a questão ambiental no Brasil a partir da geopolítica. In: LEAL, M. C. (Ed.). Saúde, ambiente e desenvolvimento: uma análise interdisciplinar. São Paulo: Hucitec/Abrasco, 1992. v. 1. p. 127-152.

BESSA FREIRE, José R. 2003. Da língua geral ao português: para uma história dos usos sociais das línguas na Amazônia. Tese (Doutorado em Literatura Comparada ) - Universidade do Estado do Rio de Janeiro, Rio de Janeiro, 2003.

BOLANOS, Omaira. 2008. Constructing Indigenous Ethnicities and Claming Land Rights in the Lower Tapajós and Arapiuns Egion, Brazilian Amazon. Tese

(Doutorado em Antropologia) - University of Florida, Gainesville, FL, 2008.

\section{ILHA}

volume 11 - número 2 
BOURDIEU, Pierre. Language and Symbolic Power. Massachusetts: Harvard University Press, 2003.

BROWDER, John. Brazil's Export Promotion Policy (1980-1984): Impacts on the Amazon's Industrial Wood Sector. The Journal of Developing Areas, Tennessee: Tennessee State University College of Business, v. 12, n. 4, p. 285$304,1987$.

COSTA, Francisco A. Grande capital e agricultura na Amazônia: a experiência Ford no Tapajós. Belém: Ed. Universitária/Ed. UFPA, 1993.

COUNDREAU, Henry. Viagem ao Tapajós. Belo Horizonte: Livraria Itatiaia/Ed. USP, 1977.

CUNHA, Manuela Carneiro da; ALMEIDA, Mauro W. B. Populações tradicionais e conservação ambiental. In: CAPOBIANCO, J. P. et al. (Eds.). Biodiversidade na Amazônia brasileira: avaliação e ações prioritárias para a conservação, uso sustentável repartição de benefícios. São Paulo: Estação Liberdade/Instituto Socioambiental (ISA), 2001. p. 184-193.

DIEGUES, Antonio Carlos. O mito moderno da natureza intocada. São Paulo: Hucitec, 1998.

DI PAOLO, Pasquale. Cabanagem: a revolução popular na Amazônia. 3. ed. Belém: CEJUP, 1990.

ESTERCI, Neide. Conflitos ambientais e processos classificatórios na Amazônia brasileira. In: ESTERCI, N.; LIMA, D.; LENA, P. (Eds.). Diversidade sociocultural e políticas ambientais. Boletim Rede Amazônica, Rio de Janeiro: IFCS, v. 1, n. 1, p. 51-62, 2002.

FAO/IBDF. Technical Report 14: Logging and Transport in the Amazon Region. Forestry Development and Research. Brasília-DF, 1978.

FATHEUER, Thomas. Novos caminhos para a Amazônia? O Programa Piloto do G-7: Amazônia no contexto internacional. Série Cadernos de Proposta, Rio de Janeiro: FASE/SACTERS, n. 2, 1998.

FOUCAULT, Michel. Vigiar e punir: história da violência nas prisões. Petrópolis: Vozes, 1984.

GALVÃO, Eduardo. Santos e visagens: um estudo da vida religiosa de Itá. São Paulo: Cia Editora Nacional, 1955.

GUIMARÃES, Roberto P. The Ecopolitics of Developments in the Third World: Politics and Environments in Brazil. Boulder, CO: Lynn Rienner, 1991.

HARAWAY, Donna J. Simians, Cyborgs, and Women: The Reinvention of Nature. New York: Routledge, 1991. 
HARRIS, Mark. What it Means to be Caboclo: Some Critical Notes on the Construction of Amazonian Caboclo Society as an Anthropological Object. Critique of Anthropology, London, UK: Sage Publications, v. 18, n. 1, p. 83-95, 1998.

HILL, Jonathan D. History, Power, and Identity: Ethnogenesis in the Americas, 1492-1992. Iowa City: University of Iowa Press, 1996.

HURREL, Andrew. Brazil and the International Politics of Amazonian Deforestation. In: HURREL, A.; KINSBURY, B. (Orgs.). The International Politics of the Environment: Actors, Interests, and Institutions. Oxford: Claredon Press, 1992. p. 392-429.

IMAFLORA/MMA/IBAMA/Banco Mundial. Plano Diretor e mapeamento comunitário da margem direita do Tapajós. Programa Piloto para Proteção das Florestas Nacionais Tropicais do Brasil (PPG-7). Relatório final. Piracicaba, 1996.

IORIS, Edviges Marta. 2005. A Forest of Disputes: Struggles Over Spaces, Resources and Social Identities in Amazônia. Tese (Doutorado em Antropologia) - University of Florida, Gainesville-Fl, 2005.

. Re-elaboração das Identidades Indígenas no Baixo Rio Tapajós. Texto apresentado no GT 31: Meio Ambiente, Território e Etnicidade. In: XXV REUNIÃO DA ASSOCIAÇÃO BRASILEIRA DE ANTROPOLOGIA (ABA), 1214 junho 2006, Goiânia-GO.

. Na trilha do manejo científico da floresta tropical: indústria madeireira e florestas nacionais. Boletim do Museu Paraense Emílio Goeldi (Ciências Humanas), v. 3, n. 3, p. 289-309, 2008.

LEMOINE, Maria Soeli A. F. 2005. La educación y la cultura de la aldea Munduruku-Takuara del Rio Tapajós: sus valores pedagógicos y antropológicos, subsídios para la educación intercultural (Amazonia-Pará, Brasil). Tese (Doutorado em Educação) - Facultad de Educación da Universidad Nacional de Educación a Distancia, Madrid, 2005.

LEROY, Jean Pierre. Uma chama na Amazônia. Rio de Janeiro: FASE/Vozes, 1991.

LIMA, Deborah M. A construção histórica do termo caboclo: sobre estruturas e representações sociais no meio rural Amazônico. Novos Cadernos NAEA, Belém-PA: Ed. UFPA, v. 2, n. 2, p. 5-32, 2002.

LINS E SILVA, Tatiana. 1980. Os curupiras foram embora: economia, política e ideologia em uma comunidade amazônica. Dissertação (Mestrado em Antropologia ) - Universidade Federal do Rio de Janeiro, Rio de Janeiro, 1980.

MEGGERS, Betty. Amazônia: a ilusão de um paraíso. Rio de Janeiro: Civilização Brasileira, 1977. 
MENÉNDEZ, Miguel. Uma contribuição para a etno-história da área TapajósMadeira. Revista do Museu Paulista (Nova Série), São Paulo: Ed. USP, v. 28, p. 289385,1981 .

. A área Madeira-Tapajós: situação de contato e relações entre colonizador e indígenas. In: CUNHA, M. C. (Org.). História dos índios do Brasil. São Paulo: Companhia das Letras, 1992. p. 315-329.

MOREIRA NETO, Carlos Araujo. 1971. A política indigenista brasileira duranteo século XIX. Tese (Doutorado em Antropologia) - Faculdade de Filosofia, Ciências e Letras, Rio Claro, 1971.

MOTA, Maria das Graças Tapajós. 2006. Organización indígena: recuperación territorial. Um sueño de lucha em la Amazônia brasileña del bajo Tapajós. Dissertação (Mestrado em Antropologia) - Pós-Graduação em Derechos Internacionales Indígenas y Recursos Hidrocarburíferos, FLACSO, Quito, Equador, 2006.

NIMUENDAJÚ, Curt. Os Tapajó. Boletim do Museu Paraense Emilio Goeldi (Ciências Humanas), Belém-PA: Museu Paraense Emilio Goeldi, n. 10, p. 93 106, 1949.

NUGENT, Stephen. Amazonian Caboclo Society: An Essay on Invisibility and Peasant Economy. Oxford: Berg, 1993.

OLIVEIRA, João Pacheco de. O nosso governo: os Ticuna e o regime tutelar. São Paulo: Marco Zero; Brasília: MCT/CNPq, 1988.

. Uma etnologia dos índios misturados? Situação colonial, territorialização e fluxos culturais. In: A viagem da volta: etnicidade, política e reelaboração cultural no Nordeste indígena. Rio de Janeiro: Contra Capa, 1999.p. 11-39.

PARKER, Eugene P. Caboclization: Transformation of the Amerindian in Amazonia (1615-1800). In: . The Amazon Caboclo: Historical and Contemporary Perspectives. Studies in Third World Societies. Williamsburg: College of William and Mary, 1985. p. 1-50.

REIS, Arthur Cesar Ferreira. Santarém: seu desenvolvimento histórico. Rio de Janeiro: Civilização Brasileira, 1979.

RIBEIRO, Darcy. Os índios e a civilização: a integração das populações indígenas no Brasil moderno. Petrópolis: Vozes, 1979.

SANTOS, Paulo R. Tapaiulândia. Santarém: ICBS/ACN Gráfica e Editora Tiagão, 1999.

SCHMINK, Marianne; WOOD, Charles. Contested Frontiers in Amazonia. New York: Columbia University Press, 1992. 
SIDER, Gerald. Lumbee Indian Cultural Nationalism and Ethnogenesis. Dialectical Anthropology, v. 1, n. 2, p. 161-172, 1976.

SUSSUARANA, Felisberto. Amazônia tapajônica santarena: enigmas e revelações. Santarém, PA: Instituto Cultural Boanerges Sena, 2000.

VIANNA, Lucila P. 1996. Considerações críticas sobre a construção da idéia de população tradicional no contexto das Unidades de Conservação. Dissertação (Mestrado em Antropologia ) - Faculdade de Filosofia, Letras e Ciências Humanas, Universidade de São Paulo, São Paulo, 1996.

WAGLEY, Charles. Amazon Town: A Study of Man in the Tropics. New York: Alfred A. Knopt, 1976.

. Foreword. In: PARKER, E. (Org.). The Amazon Caboclo: Historical and Contemporary Perspectives. Studies in Third World Societies. Williamsburg: College of William and Mary, 1985. p. VII-XVI.

Recebido em: 9/10/2010

Aceite em: 15/11/2010 